\title{
Turizmde Deneyim Ekonomisi Uygulamaları
} (Derleme Makalesi)

\author{
Experience Economy Applications in Tourism
}

Doi: 10.29023/alanyaakademik.699160

Osman ÇULHA

Doç. Dr., Alanya Alaaddin Keykubat Üniversitesi, Turizm Fakültesi, Gastronomi ve Mutfak

Sanatları Bölümü,

osman.culha@alanya.edu.tr

Orcid No: 0000-0003-2024-4582

Bu makaleye atıfta bulunmak için: Çulha, O. (2020). Turizmde Deneyim Ekonomisi Uygulamaları.. Alanya Akademik Bakıs, 4(2), Sayfa No. 495-519.

\begin{abstract}
ÖZET
Anahtar kelimeler:

Deneyim Ekonomisi,

Turizm Deneyimi,

Turizm, İ̧erik Analizi

Makale Geliş Tarihi:

05.03 .2020

Kabul Tarihi:

04.05.2020

Temel düzeyde ve standart bir turizm hizmetinin tek başına turistlerin unutulmaz bir deneyim yaşamaları için yetersiz kalması turistik destinasyonların ve işletmelerin sunacağl hizmetlerde ve etkinliklerde unutulmaz deneyimler sağlamanın yollarını aramasına neden olmaktadır. Bu noktada iki eksenli (aktif/pasif, özümseyici/sarmalayıcl) ve dört boyutlu (eğitim, eğlence, estetik ve kaçıs) deneyim ekonomisi modeli unutulmaz bir turistik deneyimin sağlanması için turizm alan yazınında yaygın olarak dikkate alınmaktadır. Bu çalışmanın amacı bu modeli bütüncül olarak öncül turizm çalışmaları ışı̆̆ında araştırmaktır. Bu doğrultuda 2007-2019 tarihleri arasinda turizmin farkl alanlarında deneyim ekonomisi modelini dikkate alan ve analiz edilmeye uygun 43 çalışma içerik analizi ile analiz edilmiştir. Çalışmalarda daha çok nicel araştırma yaklaşımın uygulandiğı, daha çok festival konusunun araştırıldı ̆̆ , konulara göre dört deneyim boyutu için çeşitli deneyim unsurlarının önerildiği, boyutların sıralamasının değistiği ve boyutların 26 farklı kavramla doğrudan veya dolaylı ilişkisinin olduğu tespit edilmiştir. Bu doğrultuda turizm hizmeti sağlayıcılarl ve araştırmacılar için öneriler sunulmuştur.
\end{abstract}

Keywords:

Experience Economy, Tourism Experience, Tourism, Content Analysis

\section{ABSTRACT}

The fact that a basic and standard tourism service alone is insufficient for tourists to have an unforgettable experience causes the tourist destinations and businesses to seek ways to provide unforgettable experiences in the services and activities to be offered. At this point, experience economy model with two-axis (active/passive, absorption/immersion) and four-dimension (education, entertainment, aesthetics and escape) is widely considered in the tourism literature to provide an unforgettable tourist experience. The aim of this study is to investigate this model as a whole in the light of previous tourism studies. Accordingly, between 2007 and 2019, 43 studies taking into account the model in diverse fields of tourism and suitable for analysis were analyzed by content analysis. In the studies, it was determined that mostly quantitative research approach was applied, mostly festival topic was investigated, diverse experience elements were proposed for four experience dimensions according to the topics, the ranking of the dimensions was 
changed, and the dimensions have direct or indirect relationships with 26 different concepts. Suggestions are provided for tourism service providers and researchers.

\section{GİRIŞ}

Bir destinasyonu ziyaret etmek ve destinasyondaki eğlenme, dinlenme, yeme ve içmeye yönelik turistik etkinliklerden yararlanmak, doğası gereği turistik bir deneyimdir (Park vd., 2010). Ancak temel düzeyde seyahat, konaklama ve yeme içme hizmetleri gibi uygulamalar turistlere tek başına deneyim sağlayamamaktadır (Rijal ve Ghimire, 2016). Turistin kendi deneyimini oluşturmada tam teşekküllü bir aktör haline geldiği ve turizm profesyonellerinin ve turistlerin rollerinin yeniden tanımlanmak zorunda olduğu turizm sektöründe; turistler tatillerinde günlük yaşamlarına göre yeni, farklı ve unutulmaz deneyim yaşamak istemekte (Thanh ve Kirova, 2018) ve bunun için yüksek bir fiyat ödemeye razı olmaktadırlar (Hwang ve Han, 2018). Turistleri hizmet sürecine dâhil etme ve aktif olarak etkileşime girme ihtiyacının karşılanması unutulmaz bir deneyimin yaşanmasında önem arz etmektedir (Rijal ve Gihimire, 2016). Bu konuda Pine ve Gilmore (1999) yüksek düzeyde ürün ve hizmet kalitesi "sağlama odaklı" hizmet ekonomisinden ziyade unutulmaz bir deneyim sunan "sahneleme odaklı" deneyim ekonomisinin uygulanmasını önermektedirler. Deneyim ekonomisinde tüketiciler ürün ve hizmeti sadece işlevsel nedenlerinden dolayı değil eşsiz, akılda kalıcı, olağan üstü ve unutulmaz deneyim yaşamak için tüketmektedirler (Oh vd., 2007; Morgan vd., 2009; Hosany ve Witham, 2010). Bu yaklaşımda hizmet türleri için standartlaşma yerine, tüketicinin kendi kişiliğini ve ilgisini yansıtan benzersiz ve kişiselleştirilmiş deneyimlere kendilerini kaptırması (sarmalanması) ve belki de bulması teşvik edilmektedir (Hayes ve MacLeod, 2007). Bunun için tüketicilerin rasyonel davranışlarına odaklanan bir hizmet ekonomisi yaklaşımının kullanılması yerine kişisel deneyimler sahnelemeyi hedefleyen deneyim ekonomisi yaklaşımının uygulanması daha uygun olacaktır (Karpov ve Merzlov, 2016). Tüm bunlar turizm hizmet sağlayıcılarını rekabet stratejilerini oluştururken ürün ve hizmetin sadece kalitesine göre değil tüketicilerin ürün ve hizmetlerden duygusal ve manevi deneyim yaşayacak şekilde oluşturmalarına zorlamaktadır (Oh vd., 2007; Morgan vd., 2009).

Bir destinasyonun değeri destinasyon tarafından sunulan ve turistler tarafindan algılanan deneyimin niteliği ve kapsamı tarafından belirlenmektedir. Bu nedenle turist deneyiminin ne olduğunun ve bir destinasyon ziyaretinin bir sonucu olarak nasıl oluştuğunun anlaşılması gerekmektedir (Oh vd., 2007). Turizm deneyiminin doğasının daha iyi anlaşılması konusunda evrensel olarak kabul edilmiş ve tanımlanmış bir yöntem bulunmamakla birlikte pek çok öncül çalışmada tüketicilerin deneyimi kavramsallaştırılmaya veya ölçülmeye çalışılmaktadır. Bu konuda Pine ve Gilmore (1999) tarafindan geliştirilen deneyim ekonomisi modeli tüketici deneyiminin anlaşılması için yaygın olarak kullanılmakta (Hwang ve Lyu, 2015), bir destinasyonun turizm sektöründe unutulmaz bir deneyim yaratma konusundaki potansiyelini öngörmekte (Rijal ve Ghimire, 2016) ve hakim bir model olarak kabul edilmektedir (tom Dieck vd., 2018). Değişik türden turizm faaliyetlerinin (şarap turları, festivaller, otel hizmetleri, gemi seyahatleri, spor etkinlikleri, kültürel ve sanatsal etkinlikler, miras ve kamp alanları, temalı parklar, müzeler) deneyim ekonomisi bağlamında kaçış, eğitim, estetik ve eğlence olarak sinıflandırılabilecek deneyimlere sahip olduğu ve bu bağlamda değerlendirmeye uygun bulunduğu kabul edilmektedir (Oh vd., 2007; Jurowski, 2009; Park vd., 2010; Hosany ve Witham, 2010; Mehmetoglu ve Engen, 2011; Ali vd., 2014; Monthiou 
vd., 2014; Hwang ve Lyu, 2015; Chang ve Lin, 2015; Suntikul ve Jachna, 2016; Shuyun ve Choong-Ki, 2017; Hwang ve Han, 2018; Thanh ve Kirova, 2018; Lee vd., 2019; Alexiou, 2020).

Tüketiciler turizm bağlamında hâlâ hizmet sektörünü deneyim sektöründen daha önemli bulmaktadırlar (Chang, 2018a; 2018b). Ancak, deneyim kaybı değerlerinin kazanç değerlerinden daha büyük olması nedeniyle tüketicileri gelecekteki deneyimsel tüketimi deneyimleme firsatını kaybetmemeye ikna etmek çok önemlidir (Chang, 2018a). Söz konusu bu durum gelecek dönemlerde işletmeler arasındaki rekabetin ürün ve hizmet kalitesinden ziyade sahnelenen deneyimlerde yaşanacağını (Pine ve Gilmore, 1998; Morgan vd., 2009) işaret etmektedir. Mal ve hizmet dışında unutulmaz deneyimler yaratmanın işletmeler için önemli olması nedeniyle deneyim ekonomisi kavramı turizm sektörünün çeşitli alt faaliyet alanlarında çok sayıda araştırmacının uzun süredir ilgisini çekmektedir (bkz. Tablo 1). Bu çalışmanın amacı popülerliğini kaybetmeyen deneyim ekonomisi kavramını turizm alanındaki çalışmalar 1şı̆̆ında aşağıdaki araştırma sorularına yanıt vererek derlemektir.

- Turizmde deneyim ekonomisi hangi yöntemler kullanılarak araştırılmaktadır?

- Deneyim ekonomisinin dört deneyim boyutu (4E) turizmin daha çok hangi alanlarında/konularında araştırılmaktadır?

- Araştırılan alanlarda/konularda dört deneyim boyutu için ne tür deneyim unsurları sunulmakta veya önerilmektedir?

- Araştırılan alanlara/konulara göre dört deneyim boyutunun sıralaması değişmekte midir?

- Dört deneyim boyutu hangi öncül değişkenlerden etkilenmekte ve hangi ardıl değişkenleri etkilemektedir?

Araştırmada ulaşılacak bulgular turizm işletmelerinin hizmet ve ürün kalitesi dışında turizmin alt faaliyetlerine göre deneyim ekonomisi bağlamında hangi deneyim alanlarına odaklanmaları ve bu alanlarda ne tür faaliyetler gerçekleştirmeleri gerektiği ve deneyimin ne tür çıktılara hizmet ettiği konusunda uygulamacılara yol gösterici olacaktır.

\section{ALAN YAZIN}

\subsection{Deneyim Ekonomisi}

"Ekonomik değer dizisi” olarak tanımlanan süreç (Pine ve Gilmore, 1998; 1999) insanoğlunun ilk olarak dünyada metaları elde ettiğini, ikinci olarak endüstriyel dönemde mal üretmeye başladığını, üçüncü olarak hizmet ekonomisi döneminde hizmet sunmaya geçtiğini ve içinde bulunduğumuz ekonomik dönemde hizmeti yeniden paketleyip deneyim olarak sunduğunu/sahnelediğini göstermektedir (Hayes ve MacLeod, 2007). Bu dört ekonomik yap1 işlevi, niteliği, vasfı, arz yöntemi, satıcısı, alıcısı ve talep faktörleri bakımından birbirinden ayrılmaktadır (Pine ve Gilmore, 1998). İnsanların çeşitli deneyim ihtiyaçlarını karşılayabilecek ekonominin yeni biçimi olan dördüncü dönem deneyim ekonomisi olarak adlandırılmaktadır (Pine ve Gilmore, 1998; 1999). Deneyim ekonomisi, tüketicilerin tüketim yoluyla duygular ve unutulmaz deneyimler yaşama arayışlarıyla karakterize edilir (Ketter, 2018). Buna göre işletme yalnızca mal veya hizmet sağlamakla kalmayıp aynı zamanda müşterilere unutulmaz bir deneyim yaşatmaktadır.

Deneyim ekonomisi tüketici katılım düzeyine göre yatay eksende pasif ve aktif katılım, tüketicileri belirli olaylarla veya performanslarla birleştiren bağlantıya göre dikey eksende özümseme ve sarmalanma olmak üzere iki eksenli modellenmektedir (Pine ve Gilmore, 1998; 
1999; Hwang ve Han, 2018) (bkz. Şekil 1). Yatay eksende yer alan aktif katılım "müşterilerin performansı veya etkinliği kişisel olarak etkilediği", pasif katılım ise "müşterilerin performansı doğrudan etkilemediği” durumları açılamaktadır (Pine ve Gilmore, 1998; 1999; Thanh ve Kirova, 2018). Diğer bir ifadeyle aktif katılımda deneyimler, tüketicilerin rafting yaparak ve eğlence ve etkinlik parklarında performans sergileyerek oluşmaktadır. Pasif katılımda deneyimler ise tüketicilerin bir tiyatroyu, sinemayı veya müzeyi ziyaret ettiklerinde oluşmakta ve zihinsel bir çabayı işaret etmektedir (Mehmetoglu ve Engen, 2011). Dikey eksende yer alan sarmalanma, etkinliğin, performansın veya çevrenin fiziksel veya sanal bir parçası olmayı tanımlarken, özümseme tüketicinin zihnini meşgul eden durumları tanımlamaktadır (Pine ve Gilmore, 1998, 1999; Oh vd., 2007; Thanh ve Kirova, 2018). Sarmalanmada tüketici deneyimin içine çekilirken özümsemede bir tüketici deneyime veya sahneye belirli bir mesafede (örneğin, bir filmi izleme) yer almaktadır (Mehmetoglu ve Engen, 2011). Bu iki eksen boyunca düştüğü yere göre deneyimler eğitim (aktif ve özümseme), eğlence (pasif ve özümseme), estetik (pasif ve sarmalanma) ve kaçış (aktif ve sarmalanma) olmak üzere dört boyuttan oluşmaktadır (Pine ve Gilmore, 1998, 1999) (bkz. Şekil 1). Bu dört boyuttan eğlence deneyimi keyfini çıkarma, eğitim deneyimi öğrenme ve bilgi elde etme, kaçış deneyimi bir eylemde bulunma veya yapma ve estetik deneyim belirli bir yerde bulunma arzusu ile ilgilidir (Chang, 2018a; Alexiou, 2020). Pine ve Gilmore (1998)'a göre en zengin deneyimler, dört deneyimin tamamını içeren, aktif ve pasif tüketici katılımının unsurlarını dengeleyen ve müşterilerin hem özümseyip hem de sarmalandığı "en etkili nokta"da (sweet spot) oluşan deneyimlerdir.

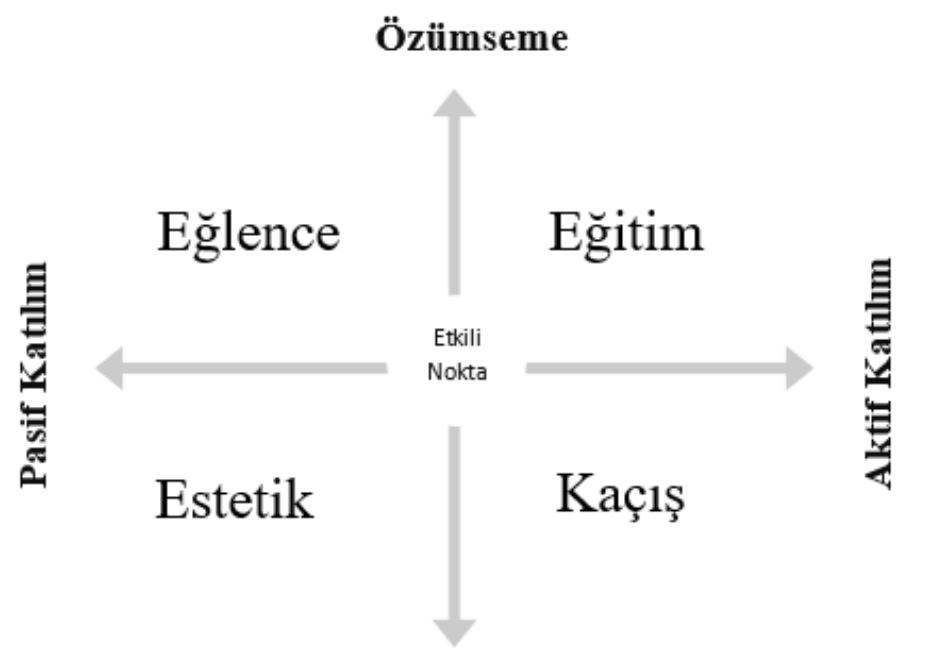

\section{Sarmalanma}

\section{Şekil 1. Bir Deneyimin Dört Alanı}

Kaynak: Pine ve Gilmore (2011, s. 46).

Ĕgitim deneyimi, yeni bir şeyler öğrenme, bilgi elde etme (Mehmetoglu ve Engen, 2011) ve beceri geliştirmeyle ilgilidir (Quadri-Felitti ve Fiore 2012; 2013; Rivera vd., 2015). Bu deneyim aktif katılımı gerektirmekte ve dikkatin zihinsel olarak tamamen deneyimle meşgul 
olması sağlanarak özümseyici bir nitelik göstermesi beklenmektedir (Pine ve Gilmore 1999; Hwang ve Lyu, 2015). Chang (2018a) tarafından da belirtildiği üzere eğitim deneyimleri, tüketicilerin aktif olarak etkinliğe katıldıklarında ve tamamen deneyime yoğunlaştıklarında oluşmaktadır.

Ĕ̆lence deneyimi, başkalarının gerçekleştirdiği etkinlikleri ve/veya performansları pasif olarak gözlemlendiğinde veya dinlendiğinde ortaya çıkmaktadır (Chang, 2018a). Bu nedenle tüketiciler etkinlikleri veya performansları doğrudan etkileyemezler (Oh vd. 2007). Ayrıca tüketiciler etkinliklerin çekiciliğine odaklanarak deneyimlerini içselleştirdiklerinden (Pine ve Gilmore, 1999) dolayı tüketicilerin etkinliklerle veya performanslarla bağlantısı sarmalanmaktan ziyade özümseyici nitelik taşımaktadır (Pine ve Gilmore, 1998; 1999). Diğer bir ifadeyle tüketicilerin dikkati zihinsel olarak tamamen deneyimle meşgul olmaktadır (Chang, 2018a).

Estetik deneyim, tüketicilerin çevresini saran fiziksel çevreyi yorumlamaları olarak tanımlanmaktadır (Hosany ve Witham, 2010). Bu deneyimde tüketiciler gözlemci olarak pasif bir rol oynamakta ve fiziksel ya da neredeyse tamamen yaşanmakta olanın bir parçası olduğunu hissetmektedirler (Chang, 2018a). Diğer bir ifadeyle tüketiciler, kendilerine sunulan çevrenin yapısını etkilemeden, bu çevrenin (destinasyon, iş veya festival) çekiciliğine kendilerini kaptırmaktadır. Ortamın özgünlük seviyesi ne olursa olsun tüketiciler pasif olarak değerlendirmelerde bulunmakta ya da ortamın duyularına hitap etme şekli tarafindan etkilenmektedirler (Oh vd., 2007). Ayrıca estetik deneyim katılımcıların kendilerini etkinliklerin veya performansların çekiciliğine bırakmaları nedeniyle sarmalanmayla ilgili bir kavramdır (Hosany ve Witham, 2010; Pine ve Gilmore, 1999). Estetik deneyim kavramı, öncül çalışmalarda "hizmet alanı" ya da "festival alanı" olarak adlandırılmaktadır (Bitner, 1992; Mason ve Paggiaro, 2012; Anıl, 2012, Bruwer, 2014; Bruwer, 2015).

Kaçış deneyimi, tüketicilerin kendilerini günlük hayattan uzaklaştığını hissettiren bir deneyimdir (Pine ve Gilmore, 1999; Thanh ve Kirova, 2018). Bu deneyim eğitim deneyiminde olduğu gibi öğretici, aynı zamanda eğlence deneyiminde olduğu gibi eğlendirici bir deneyim (Pine ve Gilmore, 1998) olsa da tüketiciler bu deneyimde farklı bir zamanda veya yerde olduğunu hissetmekte ve sarmalayıcı bir deneyim yaşamaktadır (Hosany ve Witham, 2010; Quadri-Felitti ve Fiore, 2012). Kaçış deneyimi tüketicilerin aktif olarak etkinliğin içerisinde yer aldıklarında, etkinlik performansını etkilediklerinde ve deneyimlediklerinin fiziksel veya sanal bir parçası olduklarında meydana gelmektedir (Hwang ve Lyu, 2015; Chang, 2018a). Bu nedenle tüketicilerin, mevcut performansları veya gerçek ya da sanal ortamdaki olayları etkilemesi gerekmektedir (Oh vd., 2007). Bu sayede tüketiciler rutin yaşamlarından uzaklaşma, sıkıntılarını hafifletme ve birkaç gün keyifli zaman geçirme şansına sahip olmaktadırlar (Monthiou et al., 2014). Kaçış deneyiminin daha iyi anlaşılması için "uzaklaşma", "destinasyonla sarmalanma" ve "farklı bir karaktere sahip olma” gibi üç bileşenin dikkate alınması gerekmektedir (Oh vd., 2007).

\subsection{Turizmde Deneyim Ekonomisi}

Turizm endüstrisinde deneyim, somut ve/veya soyut unsurların birleşiminden oluşan tüketim sürecinin daima bir çıktısı olup özellikle somut unsurlar olmadığında kritik bir öneme sahiptir. Özellikle turizm endüstrisinde yer alan işletmelerde (otel, restoran, temalı park, kruvaziyer, kumarhane vb.) tüketim sonrasında müşteriler elleri boş ancak her zaman deneyim ile ayrılabilmektedirler (Manhas ve Ramjit, 2013). Turizm, doğası gereği deneyim 
satan bir sektördür (Kim, 2010; Thanh ve Kirova, 2018). Stasiak (2013) turizm işletmelerini duygu, izlenim, heyecan ve anı yaratan "tatil deneyim fabrikaları" olarak nitelendirirken "yeni turistlerin" de sadece görmek ve öğrenmek için değil, aynı zamanda anlamak, deneyimlemek ve ziyaret edilen yerle doğrudan temas halinde olmak istediklerini belirtmektedir. Bu yönüyle turizmde yaratılan deneyimin tüketiciler için hayati önem taşıdığı söylenebilir (Mehmetoglu ve Engen, 2011). Seyahat etmek bilinmeyeni keşfetmek, heyecan verici maceralar yaşamak ve yeni deneyimler kazanmakla her zaman ayrılmaz bir şekilde ilişkilendirilmekte ve özellikle "tatil deneyim endüstrisinde" bir turist, "deneyim ekonomisi”nin mükemmel bir örneğini oluşturmaya devam etmektedir (Stasiak, 2013). Deneyim ekonomisinin ortaya çıkmasından önce bile turizm sektörü, sahneleme deneyiminde lider bir sektör olarak dikkate alınmıştır (Rijal ve Ghimire, 2016). Deneyim ekonomisi kavramı hem kökenleri hem de sonuçları bakımından turizm ile yakından ilgili olduğu kabul edilmektedir (Morgan vd., 2009). Bu kavram Pine ve Gilmore (1998; 1999) tarafindan ortaya atıldığından beri turizm sektörünün birçok alanında uygulanmış ve kabul görmüştür (bkz. Tablo 1). Turizmde deneyim ekonomisi uygulamaları ile ilgili ayrıntılı bilgiler aşağıdaki tabloda sunulmuştur.

Tablo 1. Turizmde Deneyim Ekonomisi Çalışmaları

\begin{tabular}{|c|c|c|c|c|c|c|}
\hline Yazarlar & \begin{tabular}{|l} 
Çalışma \\
Alanı/Konusu
\end{tabular} & $\begin{array}{l}\text { Çalışmaya } \\
\text { Konu Olan } \\
\text { Yer }\end{array}$ & Analiz Birimi & $\begin{array}{l}\text { Örneklem } \\
\text { Büyüklüğü }\end{array}$ & \begin{tabular}{|l|} 
Veri \\
Toplama \\
Yöntemi \\
\end{tabular} & \begin{tabular}{|l|} 
Veri \\
Analiz \\
Yöntemi \\
\end{tabular} \\
\hline $\begin{array}{l}\text { Oh vd., } \\
\text { (2007) }\end{array}$ & $\begin{array}{l}\text { Oda Kahvaltı } \\
\text { Hizmeti Sunan } \\
\text { Sektör }\end{array}$ & $\begin{array}{l}\text { Amerika } \\
\text { Birleşik } \\
\text { Devletleri } \\
\text { (ABD) }\end{array}$ & $\begin{array}{l}\text { İşletme sahipleri, } \\
\text { yöneticiler, } \\
\text { müssteriler, }\end{array}$ & 419 müsteri & $\begin{array}{l}\text { Görüşme } \\
\text { ve anket }\end{array}$ & $\begin{array}{l}\text { Nitel ve } \\
\text { Nicel }\end{array}$ \\
\hline $\begin{array}{l}\text { Hayes ve } \\
\text { MacLeod, } \\
(2007)\end{array}$ & \begin{tabular}{|l} 
Kentsel Miras \\
Parkurları
\end{tabular} & $\begin{array}{l}\text { İngiltere ve } \\
\text { Birleşik } \\
\text { Krallık }\end{array}$ & Broşür, bildiriler & 750 adet & $\begin{array}{l}\begin{array}{l}\text { Doküman } \\
\text { taraması }\end{array} \\
\end{array}$ & Nitel \\
\hline $\begin{array}{l}\text { Morgan vd., } \\
\text { (2009) }\end{array}$ & \begin{tabular}{|l|} 
Turistik \\
Destinasyonlar
\end{tabular} & İngiltere & $\begin{array}{l}\text { Destinasyon } \\
\text { yöneticileri }\end{array}$ & ? & Görüşme & Nitel \\
\hline $\begin{array}{l}\text { Jurowski } \\
(2009)\end{array}$ & $\begin{array}{l}\text { Eşsiz Kültürel ve } \\
\text { Doğal Kaynaklar }\end{array}$ & $\mathrm{ABD}$ & Ziyaretçiler & 1284 kişi & Anket & Nicel \\
\hline $\begin{array}{l}\text { Pikkemaat } \\
\text { vd., (2009) }\end{array}$ & Şarap Turizmi & İtalya & Turistler ve Uzmanlar & $\begin{array}{l}5 \text { şarap } \\
\text { merkezi, } 6 \\
\text { uzman ve } 38 \\
\text { turist }\end{array}$ & $\begin{array}{l}\text { Gözlem, } \\
\text { Görüşme } \\
\text { ve Anket }\end{array}$ & $\begin{array}{l}\text { Nitel ve } \\
\text { Nicel }\end{array}$ \\
\hline $\begin{array}{l}\text { Hosany ve } \\
\text { Witham } \\
\text { (2010) }\end{array}$ & $\begin{array}{l}\text { Kruvaziyer } \\
\text { Seyahati }\end{array}$ & $\begin{array}{l}\text { Singapur - } \\
\text { Hong Hong }\end{array}$ & Kruvaziyer turistleri & 169 kiși & Anket & Nicel \\
\hline $\begin{array}{l}\text { Park vd., } \\
(2010)\end{array}$ & $\begin{array}{l}\text { Uluslararas1 Film } \\
\text { Festivali }\end{array}$ & Güney Kore & Festival ziyaretçileri & 420 kişi & Anket & Nicel \\
\hline $\begin{array}{l}\text { Mehmetoglu } \\
\text { ve Engen } \\
\text { (2011) }\end{array}$ & $\begin{array}{l}\text { Müzik Festivali } \\
\text { ve Maihaugen } \\
\text { Müzesi }\end{array}$ & $\begin{array}{l}\text { Güney } \\
\text { Norveç }\end{array}$ & $\begin{array}{l}\text { Yurtiçi ve uluslararası } \\
\text { turistler }\end{array}$ & 192 kişi & Anket & Nicel \\
\hline $\begin{array}{l}\text { Quadri-Felitti } \\
\text { ve Fiore } \\
\text { (2012) }\end{array}$ & Şarap Turizmi & I & Literatür & 30 adet & $\begin{array}{l}\text { Literatür } \\
\text { taraması }\end{array}$ & I \\
\hline $\begin{array}{l}\text { Quadri-Felitti } \\
\text { ve Fiore } \\
\text { (2013) }\end{array}$ & Şarap Turizmi & $\mathrm{ABD}$ & Turistler/Ziyaretçiler & 970 kişis & Anket & Nicel \\
\hline $\begin{array}{l}\text { Ayob vd., } \\
\text { (2013) }\end{array}$ & $\begin{array}{l}\text { Halka Açık } \\
\text { Topluluk } \\
\text { Etkinliği }\end{array}$ & Malezya & Etkinlik ziyaretçileri & 508 kişi & Anket & Nicel \\
\hline
\end{tabular}


ALANYA AKADEMİK BAKIŞ DERGİSİ 4/2 (2020)

\begin{tabular}{|c|c|c|c|c|c|c|}
\hline $\begin{array}{l}\text { Lo vd., } \\
\text { (2013) }\end{array}$ & $\begin{array}{l}\text { Otel ve Resort } \\
\text { Kaplicaları }\end{array}$ & Çin & $\begin{array}{l}\text { Otel yöneticileri ve } \\
\text { müşterileri }\end{array}$ & $\begin{array}{l}8 \text { kaplica } \\
\text { yöneticisi ve } \\
5+25 \text { turist }\end{array}$ & Görüşme & Nitel \\
\hline $\begin{array}{l}\text { Manhas ve } \\
\text { Ramjit (2013) }\end{array}$ & \begin{tabular}{|l|} 
Zincir Otel \\
İşletmeleri
\end{tabular} & Hindistan & Otel müşterileri & 600 kiși & Anket & Nicel \\
\hline $\begin{array}{l}\text { Chang vd., } \\
\text { (2014) }\end{array}$ & $\begin{array}{l}\text { Yaratıcı Turizm } \\
\text { Bölgeleri }\end{array}$ & Tayvan & Turistler & 395 kişi & Anket & Nicel \\
\hline $\begin{array}{l}\text { Manthiou vd., } \\
(2014)\end{array}$ & $\begin{array}{l}\text { Geleneksel } \\
\text { Kampüs Festivali }\end{array}$ & $\mathrm{ABD}$ & Festival ziyaretçileri & 338 kişi & $\begin{array}{l}\text { Anket } \\
\text { (Çevirim } \\
\text { içi) } \\
\end{array}$ & Nicel \\
\hline $\begin{array}{l}\text { Loureiro } \\
(2014)\end{array}$ & Kırsal Turizm & \begin{tabular}{|l|} 
Güney \\
Portekiz
\end{tabular} & Kursal turistler & 222 kişi & Anket & Nicel \\
\hline $\begin{array}{l}\text { Ali vd., } \\
\text { (2014) }\end{array}$ & Resort Hotel & Malezya & Otel müşterileri & 450 kişi & Anket & Nicel \\
\hline $\begin{array}{l}\text { Rivera vd. } \\
(2015)\end{array}$ & Müzik Festivali & Aruba & $\begin{array}{l}\text { Festivale katılan Y } \\
\text { kuşağ } 1\end{array}$ & 288 kişi & Anket & Nicel \\
\hline $\begin{array}{l}\text { Hwang ve } \\
\text { Lyu (2015) }\end{array}$ & Golf Turnuvası & $\mathrm{ABD}$ & $\begin{array}{l}\text { Golf turnuvasina } \\
\text { kattlan turistler }\end{array}$ & 230 kişi & Anket & Nicel \\
\hline $\begin{array}{l}\text { Osmond vd., } \\
(2015)\end{array}$ & \begin{tabular}{|l|} 
Belirli Turist \\
Tipleri
\end{tabular} & Avustralya & Çinli yerleşik halk & 320 kişi & Anket & Nicel \\
\hline $\begin{array}{l}\text { Song vd., } \\
(2015)\end{array}$ & \begin{tabular}{|l|} 
Tapınak \\
Ziyaretleri \\
\end{tabular} & Kore & Koreli turistler & 289 kişi & Anket & Nicel \\
\hline $\begin{array}{l}\text { Radder ve } \\
\text { Han (2015) }\end{array}$ & Miras Müzeleri & Güney Afrika & Müze ziyaretçileri & 220 kişi & Anket & Nicel \\
\hline $\begin{array}{l}\text { Chang ve Lin } \\
(2015)\end{array}$ & $\begin{array}{l}\text { Yaratıcı Yaşam } \\
\text { Endüstrisi }\end{array}$ & Tayvan & $\begin{array}{l}\text { Yaratıcı yaşam } \\
\text { sektörü ziyaretçileri }\end{array}$ & 992 kiși & Anket & Nicel \\
\hline $\begin{array}{l}\text { Karpov ve } \\
\text { Merzlov, } \\
\text { (2016) }\end{array}$ & En Güzel Köyler & Rusya & Köyler & ? & ? & Nitel \\
\hline $\begin{array}{l}\text { Rijal ve } \\
\text { Ghimire } \\
(2016)\end{array}$ & \begin{tabular}{|l} 
Turizm \\
Destinasyonu
\end{tabular} & Nepal & $\begin{array}{l}\text { Girişimci, uzman, } \\
\text { temsilci, ziyaretçi }\end{array}$ & 6 kişi & Görüşme & Nitel \\
\hline $\begin{array}{l}\text { Suntikul ve } \\
\text { Jachna (2016) }\end{array}$ & Miras Alanları & Makao & Ziyaretçiler & 561 kişi & Anket & Nicel \\
\hline $\begin{array}{l}\text { Shuyun ve } \\
\text { Choong-Ki } \\
\text { (2017) }\end{array}$ & Kampçıllık & Güney Kore & Kamp turistleri & 386 turist & Anket & Nicel \\
\hline $\begin{array}{l}\text { Mahdzar vd., } \\
(2017)\end{array}$ & $\begin{array}{l}\text { Tarımsal Miras } \\
\text { Park1 }\end{array}$ & Malezya & Park ziyaretçisi & 340 kişi & Anket & Nicel \\
\hline $\begin{array}{l}\text { Shim vd., } \\
\text { (2017) }\end{array}$ & $\begin{array}{l}\text { Kumarhane } \\
\text { Etkinliği }\end{array}$ & Güney Kore & $\begin{array}{l}\text { Kumarhane } \\
\text { katılımciları }\end{array}$ & 22 kişi & Görüşme & Nitel \\
\hline $\begin{array}{l}\text { tom Dieck } \\
\text { vd., (2018) }\end{array}$ & Bilim Festivali & İngiltere & Festival katılımcıları & 220 kişi & Anket & Nicel \\
\hline $\begin{array}{l}\text { Duan vd., } \\
\text { (2018) }\end{array}$ & Şarap Turizmi & $?$ & Seyahat blokçuları & $\begin{array}{l}102 \text { blokçu, } \\
637 \text { sayfa } \\
\text { yorum }\end{array}$ & $\begin{array}{l}\text { Çevirim içi } \\
\text { blok } \\
\text { yorumu } \\
\text { tarama }\end{array}$ & Nitel \\
\hline $\begin{array}{l}\text { Thanh ve } \\
\text { Kirova } \\
\text { (2018) }\end{array}$ & Şarap Turizmi & $?$ & $\begin{array}{l}\text { Turistlerin seyahat } \\
\text { yorumları }\end{array}$ & 825 yorum & $\begin{array}{l}\text { Çevirim içi } \\
\text { yorum } \\
\text { tarama }\end{array}$ & Nitel \\
\hline $\begin{array}{l}\text { Chang } \\
(2018 a)\end{array}$ & $\begin{array}{l}\text { Ağırlama ve } \\
\text { Turizm Ürünleri }\end{array}$ & Güney Kore & $\begin{array}{l}\text { Ağırlama ve Turizm } \\
\text { Katılımc1ları }\end{array}$ & 543 kişi & $\begin{array}{l}\text { Anket } \\
\text { (Çevirim } \\
\text { içi) }\end{array}$ & Nicel \\
\hline $\begin{array}{l}\text { Chang } \\
(2018 \mathrm{~b})\end{array}$ & $\begin{array}{l}\text { Ağırlama ve } \\
\text { Turizm Ürünleri }\end{array}$ & Güney Kore & $\begin{array}{l}\text { Ağırlama ve turizm } \\
\text { müșterileri }\end{array}$ & 182 kişi & Görüșme & $\begin{array}{l}\text { Nitel ve } \\
\text { Nicel }\end{array}$ \\
\hline $\begin{array}{l}\text { Semrad ve } \\
\text { Rivera (2018) }\end{array}$ & $\begin{array}{l}\text { Elektronik Müzik } \\
\text { Festivali }\end{array}$ & Aruba & $\begin{array}{l}\text { Festival Y Kuşağı } \\
\text { katılımcıları }\end{array}$ & 274 kişi & Anket & Nicel \\
\hline
\end{tabular}




\begin{tabular}{|c|c|c|c|c|c|c|}
\hline $\begin{array}{l}\text { Hwang ve } \\
\text { Han (2018) }\end{array}$ & $\begin{array}{l}\text { Kruvaziyer } \\
\text { Seyahati }\end{array}$ & $\mathrm{ABD}$ & Kruvaziyer turistleri & 312 kişi & $\begin{array}{l}\text { Anket } \\
\text { (Çevirim } \\
\text { içi) } \\
\end{array}$ & Nicel \\
\hline Ketter (2018) & $\begin{array}{l}\text { Turizm } \\
\text { pazarlama } \\
\text { kampanyaları }\end{array}$ & $\begin{array}{l}\text { Tayland, } \\
\text { Kore, } \\
\text { İspanya, } \\
\text { Avustralya, } \\
\text { Fas, } \\
\text { Slovenya }\end{array}$ & $\begin{array}{l}\text { Internet ve basılı } \\
\text { kaynaklar }\end{array}$ & $?$ & $\begin{array}{l}\text { Kaynak } \\
\text { taraması }\end{array}$ & Nitel \\
\hline $\begin{array}{l}\text { Alexiou } \\
(2019)\end{array}$ & $\begin{array}{l}\text { Ortaçağ Gül } \\
\text { Festivali }\end{array}$ & Yunanistan & Festival ziyaretçisi & 26 ziyaretçi & Görüşme & Nitel \\
\hline $\begin{array}{l}\text { Anlive } \\
\text { Yavan (2019) }\end{array}$ & Kafe & Türkiye & Ürün ve mekân & 2 işletme & $\begin{array}{l}\text { Doküman } \\
\text { tarama ve } \\
\text { gözlem }\end{array}$ & Nitel \\
\hline $\begin{array}{l}\text { Hwang ve } \\
\text { Lee }(2019)\end{array}$ & $\begin{array}{l}\text { Üçüncü Yaş } \\
\text { Turizmi }\end{array}$ & Güney Kore & Yaşça büyük turist & 323 turist & Anket & Nicel \\
\hline $\begin{array}{l}\text { Lee vd., } \\
\text { (2019) }\end{array}$ & Temalı Park & $\mathrm{ABD}$ & Park ziyaretçileri & 530 kişi & $\begin{array}{l}\text { Anket } \\
\text { (Çevirim } \\
\text { içi }\end{array}$ & Nicel \\
\hline $\begin{array}{l}\text { Çulha ve } \\
\text { Nebioğlu } \\
(2019)\end{array}$ & $\begin{array}{l}\text { Birinci Sinıf } \\
\text { Restoran }\end{array}$ & Türkiye & $\begin{array}{l}\text { Birinci sınıf iki } \\
\text { restoran }\end{array}$ & 647 yorum & $\begin{array}{l}\text { Çevirim içi } \\
\text { yorum } \\
\text { taraması }\end{array}$ & Nitel \\
\hline $\begin{array}{l}\text { Lai vd. } \\
\text { (2019) }\end{array}$ & Etnik Mutfak & Cin & $\begin{array}{l}\text { Etnik mutfağı } \\
\text { deneyimleyen turistler }\end{array}$ & 397 kiși & Anket & Nicel \\
\hline
\end{tabular}

\section{ARAŞTIRMA YÖNTEMI}

Turizm sektöründe deneyim ekonomisi uygulamaları ulusal ve uluslararası alandaki akademik turizm çalışmaları 1şığında araştırılmıştır. "Deneyim ekonomisi”" (experience economy), "dört deneyim alanı" (four realms of experience), "Pine ve Gilmore", "Gilmore ve Pine", "4E" kelimlerinin hem İngilizcesi hem de Türkçesi ile Google Akademi (Scholor)'de en son 30.12.2019 tarihinde aranmış ve arama sonucunda toplam 55 akademik çalışmaya ulaşılmıştır. Yedi çalışmanın kavramsal nitelikte olması, dört çalışmanın başlığında deneyim ekonomi kavramı yer almasına rağmen çalışmaların bu kavramın ötesinde farklı kavramları araştırmaya yönelik olması ve bir çalışmanın da turizm dışında farklı bir alanda araştırılmış olması nedeniyle 12 çalışma analiz kapsamına dâhil edilmemiş olup 43 çalışma ile analizler gerçekleştirilmiştir. İlgili çalışmalar tek tek okunmuş ve her birinin amacı, sonucu, araştırma konusu ve yöntemini içeren detaylı çalışma künyesi oluşturulmuştur (bkz. Tablo 1). Tablodaki bilgiler dikkate alınarak içerik analizi ve betimleyici analizler uygulanmıştır. Daha özelde turizmde deneyim ekonomisi çalışmalarında hangi araştırma yöntem(ler)inin kullanıldığı (araştırma sorusu 1); çalışmanın yapıldı̆̆ 1 yer, veri toplama yöntemi, analize konu olan örneklem (analiz birimi), örneklem büyüklüğü ve verinin analiz yöntemi bağlamında incelenmiştir. $\mathrm{Bu}$ kapsamda veriler betimleyici olarak analiz edilmiş ve tespit edilen kavramlar için çevirimiçi wordart programı (WORDART, 2019) ile kelime bulutları oluşturulmuştur. Benzer uygulama deneyim ekonomisinin dört deneyim boyutunun (4E) turizmin daha çok hangi alanlarında/konularında araştırıldığını (araştırma sorusu 2) tespit etmek için gerçekleştirilmiştir. Araştırılan alanlarda (konularda) dört deneyim boyutu için sunulmakta veya önerilmekte olan deneyimlerin (araştırma sorusu 3) belirlenebilmesi amacıyla öncül çalışmalarda ulaşılan bulgular deneyimin dört boyutu (eğitim, eğlence, kaçış, estetik) altında çalışma konuları dikkate alınarak kodlanmış ve özetlenmiştir (bkz. Şekil 2). Kodlamada önerilen deneyimlerin sıklığından daha ziyade ne önerildiğinin tespit edilmesi 502 
amaçlandığından önerilen deneyimler bir kez yazılmıştır. Araştırılan alanlara/konulara göre dört deneyim boyutunun sıralamasını (araştırma sorusu 4) belirlemek için çalışmalarda rastlanma sıklıkları veya likert tipi ifadelere verilen yanıtların ortalamalarına göre boyutlar her çalışma için sıralanmıştır (bkz. Tablo 2). Eğer bir alanda (örn. festival \& etkinlik) birden fazla yapılmış çalışma olması ve çalışmalarda boyutların sıralamasının değişiklik göstermesi durumunda her boyut altında tekrarı fazla olan (mod) sayı, ilgi boyutun kaçıncı sırada olduğunu belirlemiştir. Dört deneyim boyutu hangi öncül değişkenlerden etkilenmekte ve/veya hangi ardıl değişkenleri etkilemekte olduğunun (araştırma sorusu 5) belirlenebilmesi için her bir çalışmada kurulan hipotezler ve hipotez bulguları dikkate alınmıştır. Doğrudan ve/veya dolaylı istatistiksel olarak anlamlı tüm olumlu ve olumsuz ilişkiler tablolaştırılmıştır. Daha özelde öncelikle her bir çalışmanın değişkenleri arasındaki ilişkiler, kavramların kısaltmaları kullanılarak kısaltmaların arasına ilişkinin olumlu olması durumunda "+", olumsuz olması durumunda “-” ve ilişkinin bulunmaması durumunda “/” yazılarak word dosyasına kaydedilmiştir. Kavramların birbirleriyle doğrudan olumlu veya olumsuz ilişkisi " $\mathrm{x}+\mathrm{y}$ " ve " $\mathrm{x}-\mathrm{y}$ " şeklinde gösterilirken dolaylı ilişsisi " $\mathrm{x}+\mathrm{y}+\mathrm{z}$ " ve " $\mathrm{x}-\mathrm{y}-\mathrm{z}$ " şeklinde gösterilmiştir. Deneyim ekonomisi ve boyutlarının doğrudan etkilendiği öncül ve doğrudan etkilediği ardıl değişkenler ile dolaylı etkilerinin frekansları hesaplanmıştır. Bunun için çalışmalarda hipotezleri kurulan tüm değişkenler numaralandırılarak Excel tablosuna yukarıdan aşağıya sıralanmıştır. Bu noktada çalışmalarda farklı isimlendirilen ancak aynı kavramı tanımlayan kavramların [(sadakat ve sadakat niyeti), (bellek ve canlı bellek), (memnuniyet ve memnuniyet deneyimi) vb.] sadece birinin isminin tabloya yazılmasına karar verilmiştir. Ayrıca tablonun üst satırına her bir değişkenin numarası yazılmıştır. Böylece birbirleriyle dolaylı ve doğrudan ilişkileri bulunan değişkenlerin ilişki sayısını tespit etmek için bir tablo oluşturulmuştur (bkz. Tablo 3). Tablonun hazırlanmasinda "neden-sonuç zinciri” analizine (basamaklama yöntemi) ilişkin öncül çalışmalarda oluşturulan çıkarım matrisinden esinlenilmiştir (Klenosky vd., 1993; Long ve Goldenberg, 2010; Kangal, 2013; Demir ve Yalçın, 2016). Daha önce word dosyasına yazılan ilişkiler ilişki sayısını tespit etmek için dikkate alınmış ve bu sayılar daha sonra Excel'de iki kavramın kesiştiği hücreye doğrudan ve dolaylı toplam ilişki sayıları sayıların arasına "l” işareti kullanılarak yazılmıştır (örn. 5\6). Burada birinci rakam iki kavramın doğrudan ilişki sayısını ve ikinci rakam dolaylı ilişki sayısını göstermektedir. Word dosyasında yer alan tüm değişkenlere ait ilişkiler bu yolla Excel tablosuna aktarılmıştır. Rakamların doğruluğu ve toplam ilişki sayıları bir başka araştırmacıyla birlikte iki kez kontrol edilmiştir.

\section{BULGULAR}

\subsection{Turizmde Deneyim Ekonomisi Çalışmalarında Kullanılan Araştırma Yöntemleri}

\section{Turizmde deneyim ekonomisi hangi yöntemler kullanılarak araştırılmaktadır?}

43 çalışmanın araştırma yöntemi; çalışmanın yapıldığı yer, veri toplama yöntemi, analize konu olan örneklem (analiz birimi), örneklem büyüklüğü ve verinin analiz yöntemi açısından incelenmiştir. Turizmde deneyim ekonomisini konu alan çalışmalar 24 farklı ülkede gerçekleştirilmiş olup ilk sırada Güney Kore ile Amerika Birleşik Devletleri (\%15) ve ikinci sırada İngiltere ile Malezya (\%6) yer almaktadır (bkz. Resim 1). 


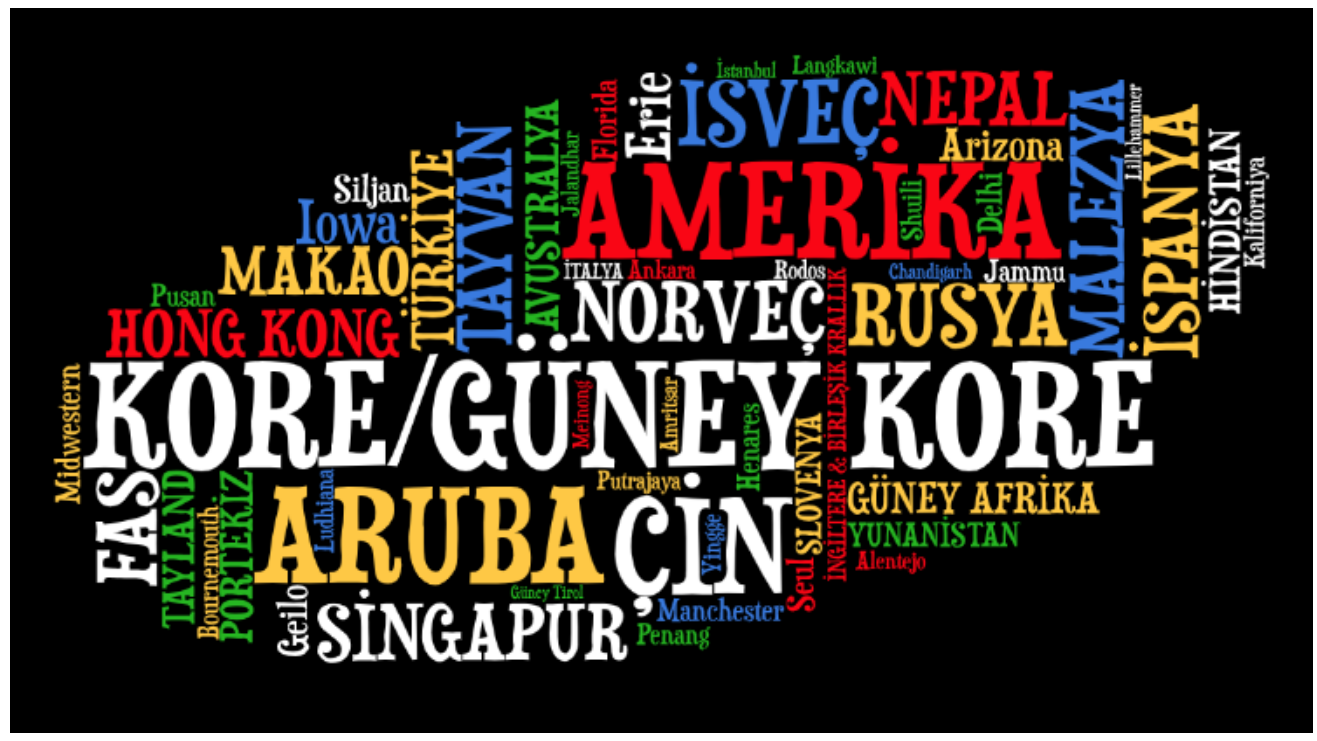

Resim 1. Çalışmaların Yapıldığı Ülke ve Şehirler

Çalışmalarda verilerin daha çok (\%64) anket yöntemine dayalı olarak toplandığı görülmektedir. Diğer taraftan verilerin toplanmasında görüşme (\%14), çevirimiçi yorumlar (\%7), doküman taraması (\%5 internet ve basılı kaynaklar) ya da karma veri toplama yöntemleri (\%2 anket \& görüşme, $\% 2$ doküman \& gözlem, $\% 2$ anket, görüşme \& gözlem) anket yöntemine göre daha az sayıda kullanılmaktadır (bkz. Resim 2). Çalışmalarda analize konu olan örneklem incelendiğinde 26 farklı kaynaktan (kişi, mekân veya yayın) verilerin toplandığı görülmektedir. Daha özelde turizmde deneyim ekonomisi için gerekli olan veriler daha çok (\%21) etkinlik ve festival ziyaretçilerinden toplanırken bunu otel müşterileri (\%8) ve müze ziyaretçileri ile sanal yorumlar (\%6) takip etmektedir (bkz. Resim 3). Çalışmaların örneklem büyüklükleri incelendiğinde anket yönteminin kullanıldığı çalışmalarda en az 38 ve en çok 1284 kişi olmak üzere ortalama 422 kişiden veri toplanmıştır. Görüşme yöntemi ile verilerin toplandığ çalışmalarda en az 6 kişi ve en fazla 182 kişi olmak üzere ortalama 47 kişi ile görüşme yapılmıştır.

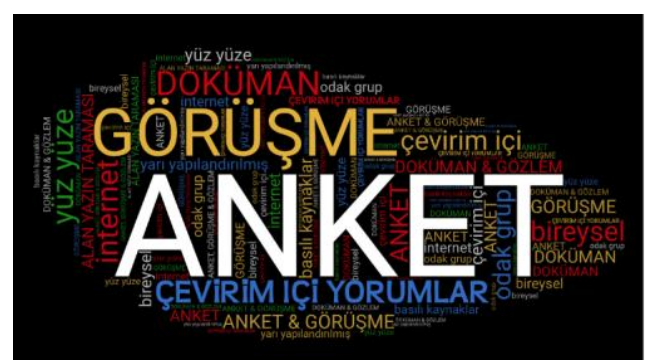

Resim 2. Veri Toplama Yöntemi

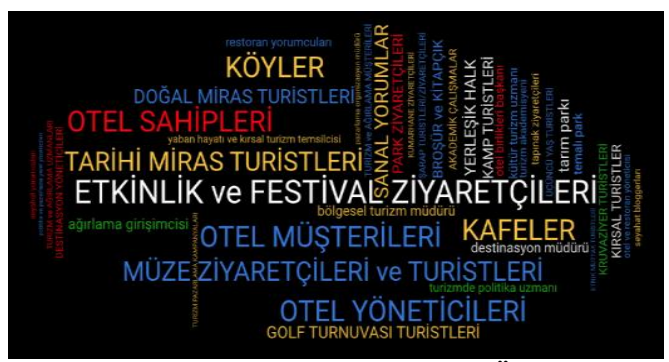

Resim 3. Analize Konu Olan Örneklem

Çalışmaların büyük çoğunluğunda (\%63) verilerin analizi için nicel bir araştırma yaklaşımı (tanımlayıcı, korelasyon, regresyon, doğrulayıcı ve keşifsel faktör, tek veya çok değişkenli varyans ile yapısal eşitlik modellemesi analizleri) benimsenirken daha az sayıda (\%25) 
çalışmada nitel (etnografik yada netnografik yaklaşımla tekil nitel analizler: Tematik, şablon, içerik, vaka, sistematik kodlama veya tematik içerik analizleri ya da çoklu nitel analizler: İçerik analizi, retorik analiz, göstergebilim analiz) ve hem nitel hem de nicel veri analizi yöntemlerinin bir arada olduğu karma analiz yöntemleri (korelasyon, doğrulayıcı faktör analizi, panel incelemesi veya içerik analizi, çapraz tablolaştırma, t testi ve ANOVA) kullanılmaktadir (\%6).

\subsection{Turizmde Deneyim Ekonomisi Çalışma Alanları/Konuları}

Deneyim ekonomisinin dört deneyim boyutu (4E) turizmin daha çok hangi alanlarında/konularında araştırılmaktadır?

Deneyim ekonomisi turizmde 17 farklı alan ve konuda yapılmış 43 çalışmaya konu olmuştur. Çalışmalarda turizm kapsamında \%16 ile festival konusu ilk sırada çalışılan konu olup bunu sırasıyla \%14 ile kültürel ve doğal alanlar (Parkurlar, Köyler, Tapınaklar, Tarihi Merkezler, Nehir, Orman, Hayelet Kasaba, Dramatik Jeolojik Alanlar) ve \%11 ile şarap turları takip etmektedir. Diğer taraftan deneyim ekonomisi bağlamında spa ve kaplıca, golf turnuvaları, kumarhane, kampçılık ve turizm kampanyaları gibi konular daha az çalışılmıştır (bkz. Resim 4).

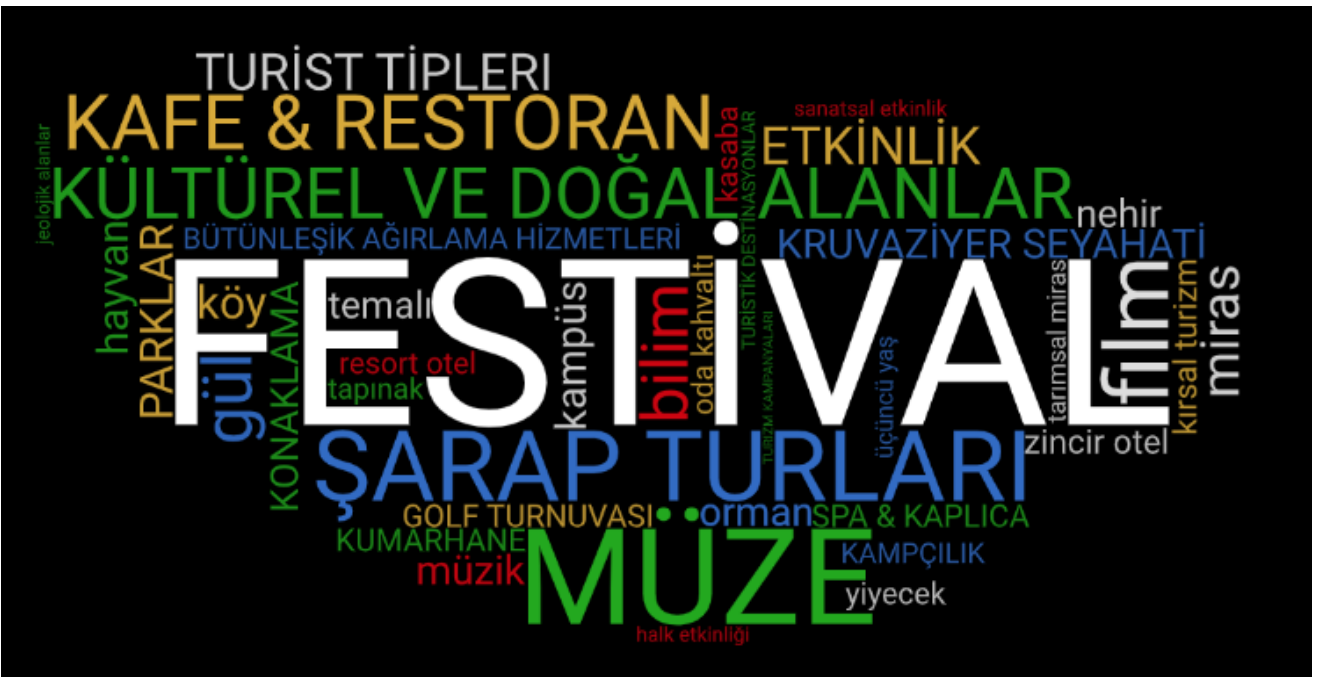

Resim 4. Çalışmalarda Dikkate Alınan Konular

\subsection{Turizmde Araştırılan Alana Göre Dört Deneyim Boyutu İçin Sunulan ve Önerilen Deneyim Unsurları}

Araştırılan alanlarda (konularda) dört deneyim boyutu için ne tür deneyim unsurları sunulmakta veya önerilmektedir araştırma sorusuna yönelik ulaş1lan bulgular şekil 2'de özetlenmiştir. Buna göre farklı konular bağlamında dört deneyim boyutu için çeşitli deneyim unsurlarının önerildiği görülmektedir. Daha özelde eğitim deneyimi için öğrenmeye ve bilgi elde etmeye, eğlence deneyimi için keyif almaya ve güzel vakit geçirmeye, estetik deneyim için bulunulan mekânı çekici kılmaya ve ilgiyi canlı tutmaya, kaçış deneyimi için zamanı 
ÇULHA

unutturmaya ve farklı bir yerde hissettirmeye yönelik etkinlikler, fiziksel ortamlar ve/veya hizmetler sunulmakta veya önerilmektedir. 


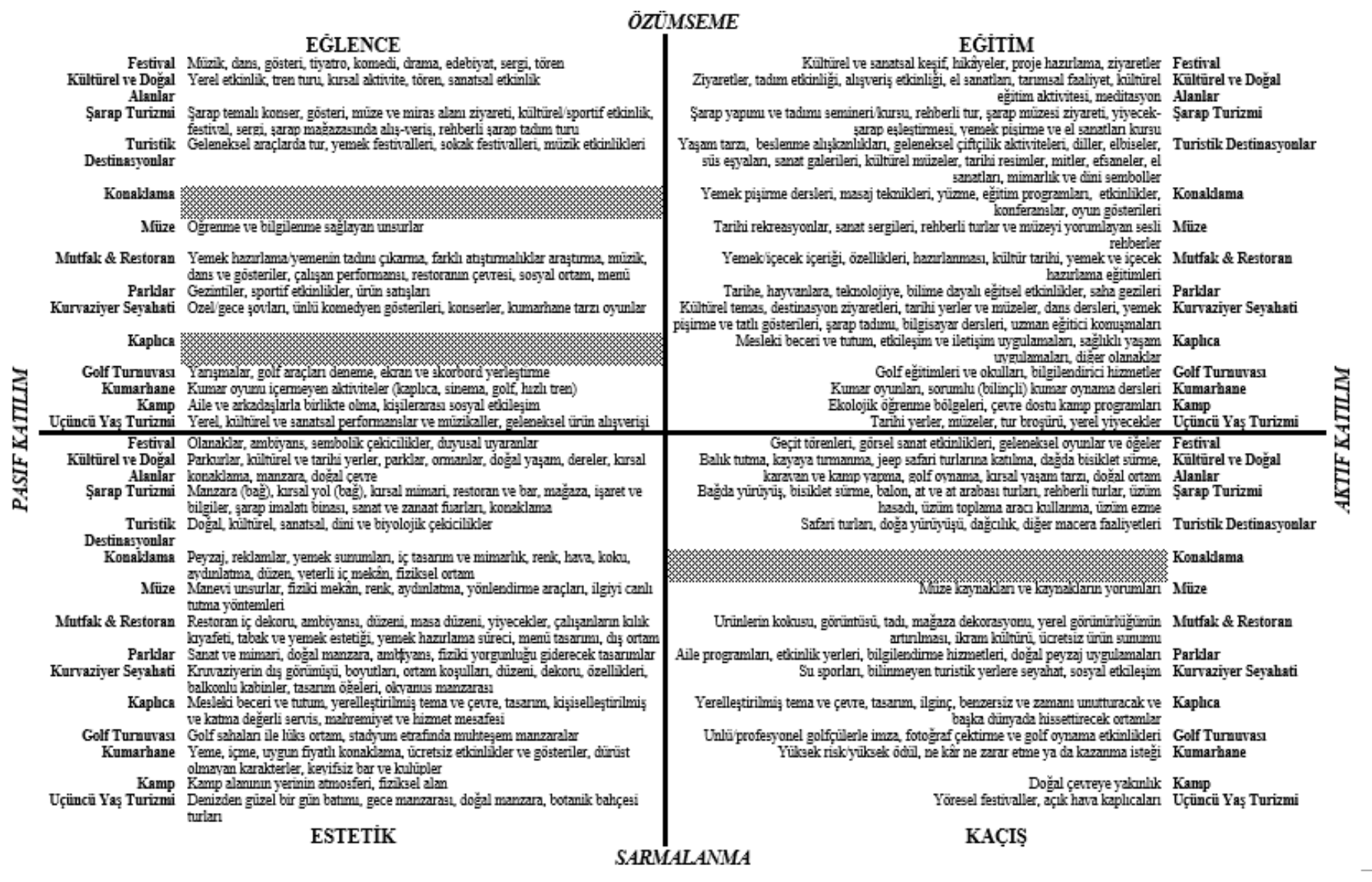

Şekil 2. Dört Deneyim Boyutuna Göre Turizmde Deneyim Ekonomisi Kaynakları 


\subsection{Araştırılan Alanlara/Konulara Göre Dört Deneyim Boyutunun Sıralaması}

Araştırılan alanlara/konulara göre dört deneyim boyutunun sıralaması farklılaşmakta mıdır?

Turizmle ilgili 13 farklı alan ve konuda yapılmış 28 çalışmada dört deneyim boyutu için rastlanma sıklıkları veya likert tipi ifadelere verilen yanıtların ortalamalarına göre boyutlar arası sıralamalar tablo 2'de gösterilmiştir.

Tablo 2. Araştırılan Alanlara/Konulara Göre Dört Deneyim Boyutunun Sıralaması

\begin{tabular}{|c|c|c|c|c|c|c|}
\hline $\begin{array}{l}\text { Çalışma } \\
\text { Alanı/Konusu }\end{array}$ & \multicolumn{2}{|c|}{ Çalışma } & Ĕgitim & Ĕ̆lence & Estetik & Kaçış \\
\hline \multirow{6}{*}{$\begin{array}{l}\text { Festival \& } \\
\text { Etkinlik }\end{array}$} & \multicolumn{2}{|c|}{ Park vd. (2010) } & 1 & 2 & 3 & 4 \\
\hline & \multicolumn{2}{|c|}{ Ayob vd. (2013) } & l & 2 & 1 & 1 \\
\hline & \multicolumn{2}{|c|}{ Manthiou vd. (2014) } & 3 & 1 & 2 & 4 \\
\hline & \multicolumn{2}{|c|}{ Rivera vd. (2015) } & 3 & 1 & 2 & 4 \\
\hline & \multicolumn{2}{|c|}{ Semrad ve Rivera (2018) } & 3 & 1 & 2 & 4 \\
\hline & \multicolumn{2}{|c|}{ Dieck vd. (2018) } & 2 & 1 & 3 & 4 \\
\hline \multirow{4}{*}{$\begin{array}{l}\text { Kültürel ve Doğal } \\
\text { Alanlar }\end{array}$} & \multicolumn{2}{|c|}{ Loureiro (2014) } & 2 & 4 & 1 & 3 \\
\hline & \multirow{3}{*}{ 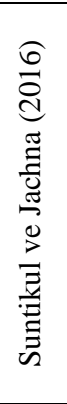 } & $\begin{array}{l}\text { Turistik } \\
\text { Deneyim } \\
\text { Genel } \\
\text { Tercihi }\end{array}$ & 4 & 1 & 2 & 3 \\
\hline & & $\begin{array}{l}\text { Tarihi Alan } \\
\text { Deneyimi }\end{array}$ & 4 & 2 & 1 & 3 \\
\hline & & $\begin{array}{l}\text { İlk Üç } \\
\text { Bireysel } \\
\text { Turistik } \\
\text { Site } \\
\text { Deneyimi }\end{array}$ & 3 & 4 & 1 & 2 \\
\hline \multirow[t]{4}{*}{ Şarap Turizmi } & \multicolumn{2}{|c|}{ Pikkemaat vd. (2009) } & 3 & 2 & 1 & 4 \\
\hline & \multicolumn{2}{|c|}{ Quadri-Felitti ve Fiore (2013) } & 2 & 3 & 1 & 4 \\
\hline & \multicolumn{2}{|c|}{ Thanh ve Kirova (2018) } & 1 & 2 & 3 & 4 \\
\hline & \multicolumn{2}{|c|}{ Duan vd. (2018) } & 4 & 3 & 2 & 1 \\
\hline \multirow{2}{*}{$\begin{array}{l}\text { Turistik } \\
\text { Destinasyonlar }\end{array}$} & \multicolumn{2}{|c|}{ Chang vd. (2014) } & 3 & 2 & 1 & 4 \\
\hline & \multicolumn{2}{|c|}{ Rijal ve Ghimire (2016) } & 1 & 4 & 2 & 3 \\
\hline \multirow[t]{2}{*}{ Konaklama } & \multicolumn{2}{|c|}{ Oh vd. (2007) } & 2 & 3 & 1 & 4 \\
\hline & \multicolumn{2}{|c|}{ Manhas ve Ramjit (2013) } & 4 & 1 & 2 & 3 \\
\hline Müze & \multicolumn{2}{|c|}{ Radder ve Han (2015) } & 2 & 3 & 1 & 4 \\
\hline \multirow{2}{*}{$\begin{array}{l}\text { Mutfak \& } \\
\text { Restoran }\end{array}$} & \multicolumn{2}{|c|}{ Lai vd. (2019) } & 3 & 4 & 2 & 1 \\
\hline & \multicolumn{2}{|c|}{ Çulha ve Nebioğlu (2019) } & 4 & 2 & 1 & 3 \\
\hline Parklar & \multicolumn{2}{|c|}{ Lee vd. (2019) } & 3 & 1 & 2 & 4 \\
\hline \multirow{2}{*}{$\begin{array}{l}\text { Kruvaziyer } \\
\text { Seyahati }\end{array}$} & \multicolumn{2}{|c|}{ Hosany ve Witham (2010) } & 3 & 2 & 1 & 4 \\
\hline & \multicolumn{2}{|c|}{ Hwang ve Han (2018) } & 3 & 2 & 1 & 4 \\
\hline Kaplica & \multicolumn{2}{|c|}{ Lo vd. (2013) } & 3 & I & 1 & 2 \\
\hline Golf Turnuvası & Hwa & & 4 & 2 & 1 & 3 \\
\hline Kumarhane & Shin & & 4 & 1 & 2 & 3 \\
\hline $\begin{array}{l}\text { Üçüncü Yaş } \\
\text { Turizmi }\end{array}$ & Hwa & & 4 & 3 & 2 & 1 \\
\hline
\end{tabular}


Tabloya göre festival ve etkinlik konusundaki çalışmaların göreceli olarak çoğunluğunda birinci sırada eğlence, ikinci sırada estetik, üçüncü sırada eğitim ve dördüncü sırada kaçış deneyimi yer almaktadır (EĞL $>$ EST $>$ EĞT $>$ KAÇ). Benzer deneyim sıralaması parklardaki deneyimlerde de görülmektedir (EĞL $>$ EST $>$ EĞT $>$ KAÇ). Kültürel ve tarihi alanları konu edinen çalışmalarda estetik daha çok birinci sırada, kaçış üçüncü sırada yer alırken eğlence ve eğitim son sırayı paylaşmaktadır (EST $>$ ? $>$ KAÇ $>$ EĞL $=E \breve{G T}$ ). Şarap turizminde ise çoğunlukla estetik deneyim birinci sırada, kaçış deneyimi son sırada yer alırken eğlence deneyimi eşit sıklığa sahip olarak ikinci ve üçüncü sırayı paylaşmaktadır. Eğitim deneyiminin ise dört çalışmada da farklı sıralarda yer aldığı görülmektedir (EST>EĞL $>$ KAÇ). Ayrıca dört deneyim boyutu müze için estetik, eğitim, eğlence ve kaçış (EST>EĞT $>$ EĞL $>$ KAÇ); kruvaziyer seyahati için estetik, eğlence, eğitim ve kaçış (EST $>$ EĞL $>$ EĞT $>$ KAÇ); kaplıca için estetik, kaçış ve eğitim (EST>KAÇ>EGT); golf turnuvası için estetik, eğlence, kaçış ve eğitim (EST>EĞL $>$ KAÇ>EĞT); kumarhane için eğlence, estetik, kaçış ve eğitim (EĞL $>$ EST $>$ KAÇ $>$ EĞT) ve üçüncü yaş turizmi için kaçış, estetik, eğlence ve eğitim (KAÇ $>$ EST $>$ EĞL $>$ EĞT) şeklinde sıralanmaktadır. Bunların dışında turistik destinasyonlar, konaklama ve mutfak/restoran konularının her birinin farklı çalışmalara göre kendi içlerinde deneyim sıralamaları farklılık göstermesinden dolayı deneyim boyutlarının sıralanması uygun görülmemiştir. Alan ve konu ayrımı yapılmaksızın sıralamalar dikkate alındığında birinci sırada estetik, ikinci sırada eğlence, üçüncü sırada eğitim ve dördüncü sırada kaçış deneyimi gelmektedir (EST>EĞL>EĞT>KAÇ).

\subsection{Dört Deneyim Boyutunun Öncül ve Ardıl Değişkenleri}

Dört deneyim boyutu hangi öncül değişkenlerden etkilenmekte ve hangi ardıl değişkenleri etkilemektedir?

Toplam 25 nicel çalışmada deneyim ekonomisinin boyutlarının (eğitim, eğlence, estetik ve kaçış) kendi aralarındaki öncül ve ardıl ilişkileri dikkate alınmadığında beş farklı öncül ve 21 ardıl olmak üzere toplam 26 farklı kavramla doğrudan veya dolaylı olumlu veya olumsuz ilişkisi bulunmaktadır. Diğer taraftan deneyim ekonomisi ve boyutlarının hiç birinin 11 ardıl değişken (reklam etkinliği, sosyal değer, ilgilenim, algılanan davranışsal kontrol, davranışlara yönelik tutum, marka tutumu, marka özdeşliği, marka bilinci, marka bağlılı̆̆1, ziyaretçi bağlılığı, marka sadakati) ile ilişkisi bulunmamakta veya araştırılmamaktadır (bkz. Tablo 3). Deneyim ekonomisinin ve boyutlarının hem doğrudan hem de dolaylı olarak etkisi daha çok memnuniyet (29\14) ve bellek (23\6) üzerinde görülmektedir. Memnuniyet ve bellek ile karşılaştırıldı̆̆ında deneyim ekonomisinin ve boyutlarının sadakat (9\1), yaşam kalitesi (7\1),

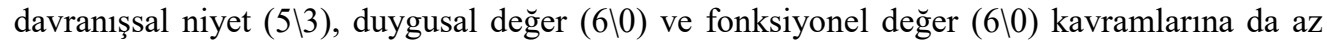
sayıda olumlu veya olumsuz etkisi bulunmaktadır. Buna rağmen deneyim boyutlarının memnuniyet dışında en fazla sayıda (0\7) dolaylı olarak ağızdan ağıza iletişim kavramı üzerinde etkisi görülmektedir. Diğer taraftan deneyim ekonomisinin ve boyutlarının unutulmaz deneyim (2\0), çevresel değer (2\0), tekrar ziyaret niyeti (2\0), mekân bağlılı̆̆1

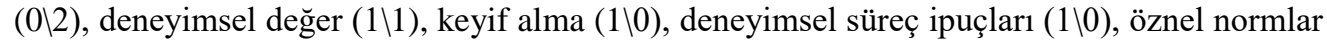
(1\0) ve elektronik iletişim (1\0) üzerinde daha az sayıda olumlu veya olumsuz etkisi bulunmaktadır. Deneyim ekonomisi kavramı üzerinde sınırlı sayıda da olsa etkisi tespit edilen öncül tek kavram etkinlik özellikleridir. Deneyim ekonomisinin boyutlarından estetik deneyim eğitim, eğlence ve kaçış deneyiminin az sayıda da olsa öncülü olarak dikkate alınmaktadır. Bunlara ek olarak otel büyüklüğü, yaş, ikamet yeri ve cinsiyet değişkenlerine göre deneyim ve/veya boyutları bakımından sınırlı sayıda anlamlı farklılık bulunmaktadır. 
Ayrıca deneyim ekonomisi boyutları içerisinde öncül ve ardıl değişkenlerle doğrudan ve dolaylı ilişkisi en fazla olan boyut estetik deneyim (41\16) iken, bunu sırayla eğitim (29\6), eğlence (28\5) ve kaçış (24\6) deneyimleri takip etmektedir. 
Tablo 3. Deneyim Ekonomisi ve Boyutlarının Öncül ve Ardıl Değişkenlerle Doğrudan ve Dolaylı İlişki Sayısı

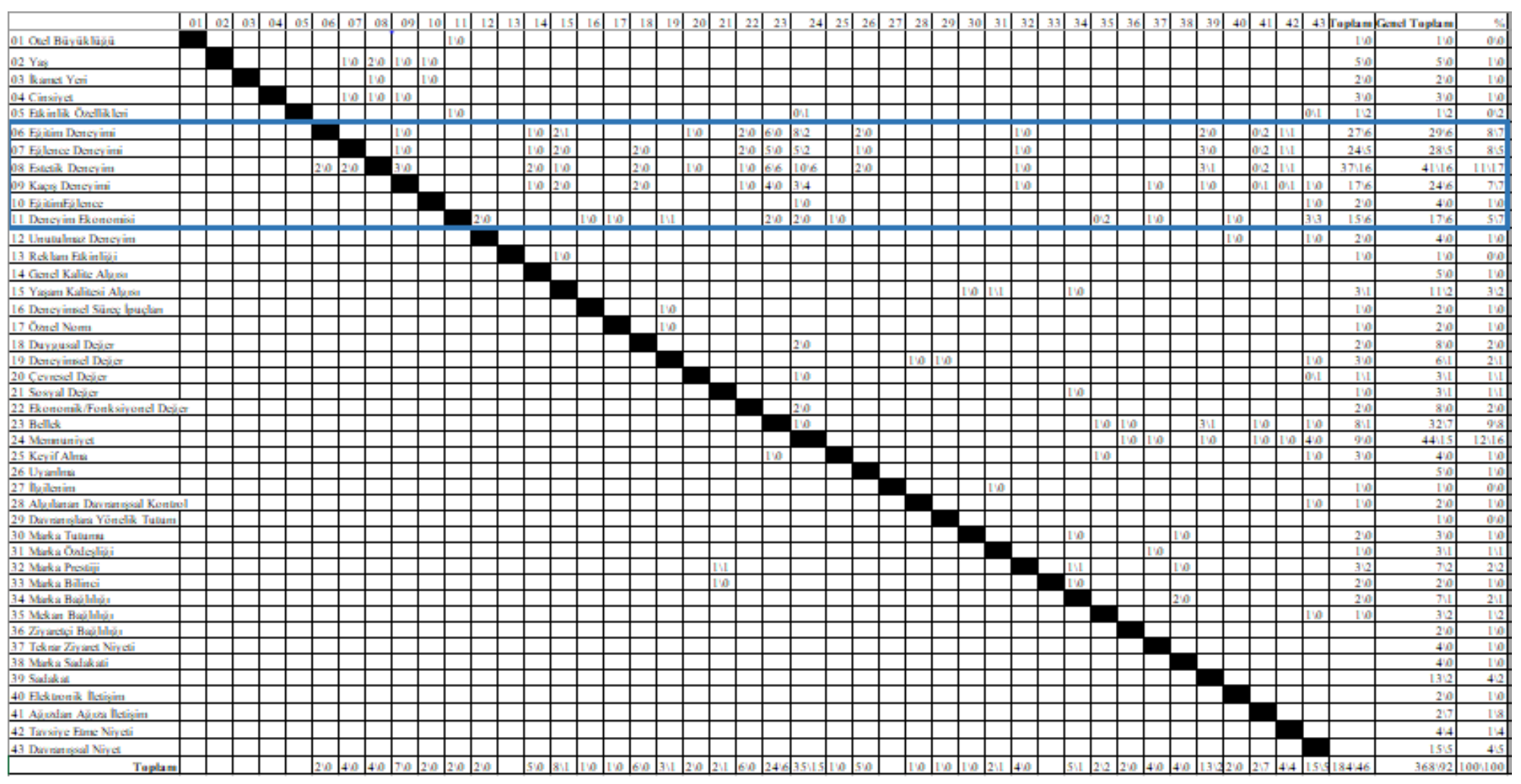




\section{SONUÇ ve ÖNERILER}

Hizmet kalitesi dışında turistlerin turistik hizmetlerde unutulmaz deneyim yaşamaya yönelik ihtiyaçlarına cevap veren işletmeler veya destinasyonlar rekabet avantajı elde edebilirler. Öncelikli olan konu bu kapsamda turistlerin deneyimlerinin neler olduğunun belirlenmesidir. $\mathrm{Bu}$ noktada hizmet ekonomisinden ziyade deneyim ekonomisi modeli turistlerin deneyimlerinin anlaşılması için 2000'li yılların başlarından itibaren günümüze kadar yaygın olarak dikkate alınan bir kavram olmuştur. Bu çalışmanın amacı popülerliğini kaybetmeyen deneyim ekonomisi kavramını bütüncül olarak turizm alanındaki çalışmalar ışığında araştırmaktır. Bu doğrultuda, bu deneyimin araştırılmasında daha çok hangi yöntemlerin uygulandığı, turizmde hangi alan/konuların bu deneyimin merkezinde yer aldığı, konulara göre ne tür deneyim unsurlarının önerildiği, deneyimlerin sıralamasının değiş̧ip değişmediği ve ilişkili olduğu kavramların neler olduğu araştırılmak istenmiştir.

Deneyim ekonomisini konu alan çalışmalarda nitel yaklaşıma göre daha çok nicel araştırma yaklaşımının benimsendiği görülmektedir. Çalışmalarda dikkate alınan yaklaşımlara bağlı olarak verinin toplanması, analize konu olan örneklem ve sayısı, verinin analiz yöntemi değişiklik göstermektedir. Çalışmalar daha çok Güney Kore ile Amerika Birleşik Devletleri'nde gerçekleştirilmektedir. Deneyim ekonomisi daha çok festival konusunda araştırılırken spa ve kaplıca, golf turnuvaları, kumarhane ve kampçılık gibi konular sınırlı sayıda çalışmanın ilgisini çekmiştir. Bu bulgular gelecekte deneyim ekonomisini çalı̧̧acak araştırmacıların çalışma konusu ve araştırma yaklaşımı bağlamında boşluğun ne olduğu ile ilgili bilgi verici niteliktedir. Bu noktada deneyim ekonomisinin spa ve kaplıca, golf turnuvaları, kumarhane ve kampçılık alanlarına ek olarak Quadri-Felitti ve Fiore (2013)'nin de belirttiği gibi kayak ve tırmanma gibi dağ temelli veya rafting, kuş gözlemciliği ve balık tutma gibi doğa temelli turizm türlerinde de araştırılması önerilmektedir. Ayrıca nicel yaklaşımlardan daha ziyade nitel yaklaşımlara ya da nitel ve nicel yaklaşımların birlikte uygulandığı araştırmalara ağırlık verilmesi kavramın derinlemesine incelenmesine olanak sağlayacaktır. Kavramın farklı turistik destinasyonlarda da benzer konularda araştırılması kavramın destinasyonlara göre farklılığının olup olmadığın karşılaştırılmasına imkân verecektir.

Dört deneyim boyutunun sıralaması araştırılan alanlara/konulara göre farklılık göstermektedir. Örneğin kültürel ve tarihi mekânlar, şarap turizmi, müze, kruvaziyer seyahati, kaplıca ve golf turnuvası ziyaretçilerin daha çok estetik deneyim yaşamalarına, festival, park ve kumarhane ise ziyaretçilerin eğlence deneyimi yaşamalarına imkân sağlamaktadır. Diğer taraftan eğitim deneyimi kültürel ve tarihi mekânlar, kaplıca, golf turnuvası ve kumarhane konularında, kaçış deneyimi ise festival, park, şarap turizmi, müze, kruvaziyer seyahati ve üçüncü yaş turizmi konularında ziyaretçiler tarafindan daha az yaşanan bir deneyim olmuştur. Söz konusu bu farklılığın her bir konunun doğası gereği farklı özelliklere sahip olmasından kaynaklandığ 1 düşünülmektedir. Hatta aynı konuda (turistik destinasyonlar, konaklama ve mutfak \& restoran) yapılmış çalışmalarda bile deneyim boyutlarının sıralaması farklılık gösterebilmektedir. Alan/konu ayrımı yapılmaksızın turizm hizmetlerinin geneli düşünüldüğünde estetik daha fazla yaşanılan bir deneyim olmaktadır. Bu durum deneyimlerin estetik bir değerlendirme ile başlaması, estetiğin kaçış, eğitim ve eğlence deneyimlerinin güçlü bir göstergesi olması ve önemini belirlemesi (tom Dieck vd., 2018) ile açıklanabilir. Bu doğrultuda ürün geliştirme ve yatırımların her bir hizmetin veya etkinliğin doğasına özgü olarak yapılmasına ve bu hizmetlerdeki ve/veya etkinliklerdeki doğal, kültürel ve sosyal 
çevrenin ziyaretçileri sarmalayacak bir düzene, ambiyansa, çekiciliğe ve doğal bir manzaraya sahip olmasına daha fazla dikkat edilmelidir. Özellikle doğal ortamlardaki estetiğin korunmasına yönelik yapılacak düzenlemeler doğa temelli gerçekleştirilecek turizm aktivitelerinin (şarap turizmi vb.) ekonomik değerini artırabilmektedir (Quadri-Felitti ve Fiore, 2013). Estetik deneyimin yanı sıra festival, park ve kumarhane başta olmak üzere şarap turizmi, kruvaziyer seyahati ve golf turnuvası gibi turizm etkinliklerinin pazarlanmasında, eğlence göz ardı edilmemesi gereken deneyim boyutlarından biridir. Müzik, dans, gösteri, tiyatro, komedi, drama, sergi, tören, kültürel ve sportif etkinlik, konser ve alışveriş imkânları, tadım turları ile ziyaretçilerin turizm etkinliklerini özümsemesi ve bu etkinliklerden keyif alması sağlanabilir. Pine ve Gilmore, (1998) eğlence deneyiminin tiyatro ve temalı eğlence parklarından ziyade yemeğin eğlenmeyi desteklemesi "eatertaintment" nedeniyle temalı restoranlarda da (Hard Rock Cafe, Planet Hollywood veya House of Blues) yaşanmaya başlandığını belirtmektedirler. Bu durum araştırma kapsamında analize konu olan birinci sınıf restoranlarda kısmen tespit edilse de (Çulha ve Nebioğlu, 2019) etnik mutfaklarda eğlence deneyiminin yaşandığını söylemek güçtür (Lai vd., 2019). Etnik mutfak bağlamında konukların sürecin içerisine dâhil edildiği otantik bir ortamda kendilerine yemek yapma firsatı sağlanarak ya da etkileyici yöresel sunumlar izletilerek etnik mutfakları hem öğrenmeleri hem de hizmetten keyif almaları sağlanabilir. Eğlence deneyiminin yaşanmadığ hizmetlerden biri de spa ve kaplicalardır. Bunun en temel nedeni spa hizmetlerinden yararlananların çevre ve personel ile etkileşime girmeden bu hizmeti pasif bir şekilde özümsediği bir film, konser veya gösteriye gitmek gibi bir etkinlik olmamasıdır (Lo vd., 2013).

Diğer taraftan kaçış, ziyaretçiler tarafından gerek özel turizm etkinliklerinde (festival, park, şarap turizmi, müze, kruvaziyer seyahati ve üçüncü yaş turizmi) gerekse turizm hizmetleri genelinde düşük değerlendirme yapılan bir deneyim boyutudur. Bu durum deneyimin diğer boyutları ile karşılaştırıldığında destinasyonda veya bir etkinlikte sunulanların (çeken faktörler) kaçış deneyiminin doğrudan belirleyicisinin olmaması (Park vd., 2010) ile açıklanabilir. Daha ziyade kaçış deneyimi, deneyimin diğer üç boyutundan ve genel deneyimlerden etkilenen psikolojik sonucunun bir özetidir. Quadri-Felitti ve Fiore (2013) ise bu durumu ziyaretçilerin destinasyonda yeterli zaman geçirmemeleri ile açıklamaktadırlar. Yazarlara göre bir destinasyonda 1,4 gece tahmini ortalama kalışları, ziyaretçilerin destinasyonla sarmalanır hale gelebilmeleri ve kaçış deneyimini tam olarak yaşayabilmeleri için yeterli bir zaman değildir. Bu nedenle Oh vd. (2007) kaçış olgusunun daha yakından incelenmesini ve kavramın net olarak anlaşılması için kaçışın "sadece uzaklaşma", "destinasyonla sarmalanma" ve "farklı bir karaktere benzeme" gibi üç bileșenin dikkate alınmasını önermektedirler. Yazarlara göre bu üç bileşen farklı turizm davranışlarını işaret etmekte ve farklı destinasyon yönetim yaklaşımları uygulamayı gerektirmektedir. Örneğin sürekli yaşadığ 1 çevreden sadece uzaklaşmak için etkinliklere pasif katılım gösteren bireyler ile destinasyondaki etkinliklere aktif katılarak sarmalanma veya farklı bir kimliğe bürünen bireylerin bu deneyimlerinin daha kapsamlı ölçüm araçlarıyla değerlendirilmesi önerilmektedir. Bu nedenle Oh vd. (2007)'nin de belirttiği gibi deneyimin her bir boyutu uzun vadede anlamlı alt boyutlara ayrılarak incelenebilir. Kaçış deneyiminin yanı sıra eğitim deneyimi de kültürel ve tarihi mekânlar, kaplıca, golf turnuvası ve kumarhane gibi konularda ön planda yer alan bir deneyim değildir. Bu durumun sebebi özellikle kültürel ve tarihi mekânlar ile sportif etkinliklerin öğretici bir yanının bulunmasına rağmen söz konusu etkinliklerde estetik deneyimi yaşatacak unsurların eğitsel unsurlara göre daha baskın olması 
ile açıklanabilir. Sonuç olarak farklı turizm hizmetlerinde deneyim boyutlarının her birinin eşit öneme sahip olmaması ile ulaşılan bulgu turizm işletmelerinin ve destinasyonlarının sınırlı kaynaklarını hangi deneyim alanında en iyi şekilde kullanmaları gerektiğine rehberlik edecektir. Diğer bir ifadeyle Thanh ve Kirova (2018)'nın da vurguladığı gibi her bir turistik işletmenin ve destinasyonun faaliyet alanına göre deneyim boyutlarını farklı derecelerde pazarlama stratejilerinde ön plana çıkarmaları beklenmektedir. Ancak bu noktada dikkat edilmesi gereken her bir deneyim boyutunun benzersiz olmasi ve ideal bir turizm deneyiminin oluşturulması için bu dört boyutun ideal bir kombinasyonunun sağlanmasının gerekliliğidir (Pine ve Gilmore, 1999; Oh vd., 2007).

Değişik türden turizm hizmetlerinde sunulan deneyimleri dört boyut altında tanımlamaya odaklanan deneyim ekonomisi boyutlarının potansiyel öncüllerini ve sonuçlarını dikkate almak yararlı olacaktır (Oh vd., 2007). Bu bağlamda deneyimin ve boyutlarının öncüllerine kıyasla daha çok sonuçlarının araştırılmasına odaklanılmaktadır. Diğer bir ifadeyle deneyim ekonomisinin ve boyutlarının "memnuniyet" ve "bellek" üzerindeki etkisinin araştırılması daha fazla ilgi görmektedir. Bu değişkenleri "sadakat", "yaşam kalitesi”, "davranışsal niyet", "duygusal değer" ve "fonksiyonel değer" gibi değişkenler takip etmektedir. Deneyim ekonomisinin "unutulmaz deneyim", "çevresel değer", "tekrar ziyaret etme niyeti", "mekân bağl1lığı", "deneyimsel değer", "keyif alma", "elektronik iletişim" gibi değişkenler ile ilişkisi ise daha az dikkate alınmaktadır. Bu bulgu Oh vd. (2007) tarafindan "Turizm deneyimlerinin belirli sonuçları öncüllerinden daha az dikkat çekmektedir." görüşünü yanlışlar niteliktedir. Belki de bu durum turizm alanında deneyim ekonomisi konusunda öncül çalışma yürüten $\mathrm{Oh}$ vd. (2007)'nin deneyim ekonomisinin sonuçlarının daha az araştıııldığı ile ilgili önerisine bugüne kadar yapılan araştırmalar tarafindan kulak verildiğinin bir göstergesi olarak da yorumlanabilir. Ancak etkinlik özellikleri kavramı deneyim ekonomisi kavramı üzerinde bugüne kadar yapılan çalışmalarda etkisi tespit edilen öncül tek kavramdır. Oh vd. (2007)'ne göre deneyimin çıtıllarıyla ilişkilerinin belirlenmesi destinasyon yönetimi için önem taşımaktadır. Çünkü bu çıktılar ile olan ilişkiler turizm pazarlamacılarına sadece destinasyonun sunduklarının teşhisine yönelik değerlendirmeler sağlamaz bunun yanı sıra turistlerin gelecekteki destinasyon seçimini etkileyen faktörlerin daha iyi anlaşılmasına olanak sağlar. Deneyimin hangi değişkenlerden etkilendiğinin ve deneyimin hangi değişkenleri etkilediğinin bilinmesi sadece destinasyon özelinde değil bunun yanı sıra turistik hizmetlerin ve etkinliklerin daha etkili yönetilmesine katkı sağlayacaktır. Nitekim bir işletmenin deneyimler yoluyla müşteriler için değer yaratmakta başarılı olup olmadığı hakkında bilgi sahibi olması işletme için kritik bir öneme sahiptir (Mehmetoglu ve Engen, 2011). Ayrıca tespit edilen değiş̧enler arası ilişkilerin sıklığı özellikle bundan sonra gelecek çalışmalarda odaklanılması gereken kavram(lar)ın hangisi olacağı konusunda bilgi verici niteliktedir. Bu noktada deneyim ekonomisi ile ilişkisi daha az kurulan kavramlar ile aralarında ilişki tespit edilemeyen veya araştırılmayan kavramların (reklam etkinliği, sosyal değer, ilgilenim, algılanan davranışsal kontrol, davranışlara yönelik tutum, marka tutumu, marka özdeşliği, marka bilinci, marka bağlılığı, ziyaretçi bağlılığı, marka sadakati) gelecek çalışmalarda daha fazla dikkate alınması önerilmektedir.

Turizmin farklı konularında yapılmış bir çok çalışmanın aksine estetik, eğitim, eğlence ve kaçış gibi deneyim ekonomisi boyutları "aynı düzeyde" olmayabilmektedir (Park vd., 2010; tom Dieck vd., 2018; Lai vd., 2019). Örneğin Park vd. (2010)'ne göre kaçış deneyimi, ziyaretçinin bir etkinlikte (festival) son derece tatmin edici eğitim, eğlence ve estetik deneyimin bir sonucu olarak aktif katılım ve çevrenin kendisini sarmalamasından 514 
kaynaklanan psikolojik bir faydadır. Dolayısıyla destinasyonda veya etkinlikte sunulanlar (çeken faktörler) kaçış deneyiminin doğrudan belirleyicisi olmayıp kaçış deneyimi daha ziyade genel deneyimden etkilenen psikolojik sonucun bir özetidir. Dieck vd. (2018)'ne göre görünür işaretler insanların insanlar ve metalar hakkında yargılarda bulunmak için kullandıkları ilk ipuçlarıdır. Yazarlar bu durumun ziyaretçi deneyiminin yaratılmasında da önemli olduğunu savunmaktadırlar. Dahası ilk izlenimin önemli olduğunu, estetiğinin deneyim kaynağı olduğunu ve bunun eğitim, kaçış ve eğlencede artışa yol açtığını iddia etmektedirler. Dolayısıyla deneyimler estetik bir değerlendirme ile başlar ve estetik deneyim festival bağlamında kaçış, eğitim ve eğlencenin güçlü bir göstergesi olur. İki çalışmanın iddiaları ve bulguları dikkate alındığında deneyim ekonomisi kavramının dört boyutunun birbirinden bağımsız olmadığı söylenebilir. Buna ek olarak diğer önemli bir tespit deneyim ekonomisinin boyutlarına ait sınırların son derece geçirgen, yapılandırılmamış ve düzensiz olmasıdır (Oh vd., 2007; Jurowski, 2009; Park vd., 2010; Radder ve Han, 2015; Çulha ve Nebioğlu, 2019). Örneğin bu geçirgen yapı nedeniyle müze veya restoranda eğitim ve eğlence deneyimleri bir arada yaşanmakta ve örtüşmekte olup eğitim-eğlence "edutaintment" ismiyle boyutlandırılmaktadır (Radder ve Han, 2015; Çulha ve Nebioğlu, 2019). Benzer şekilde şarap turizmi bağlamında bağda veya göl kıyısında ancak gün batımında yaşanılacak öğrenme firsatı estetik ve eğitim deneyiminin birlikte bir deneyimin (edusthetic) yaşanmasına olanak sağlar (Quadri-Felitti ve Fiore, 2013).

Pine ve Gilmore (1998; 1999) tarafından öne sürülen deneyim ekonomisi kavramı ve dört deneyim boyutu turizmin 17 farklı alanında/konusunda yapılmış 43 çalışmanın öznesi olmasına rağmen turizm bağlamında tüm deneyim boyutlarını kapsamaması (Aho, 2001 aktaran Lo vd., 2013), acil ihtiyaçlarının ötesine bakacak zamanı olmayan ve yatırım yapamayan küçük işletmeler ile operasyonel özgürlüğe veya yeterli bütçeye sahip olmayan büyük ulusal işletmelerde uygulanamayacağı (Morgan vd., 2009), destinasyonun bir bütün olarak değerlendirdiğinde bireysel turizm unsurlarının (örn. konaklama, yemek, şaraphane ve turistik yerler) tek tek katkılarını tespit edememesi (Quadri-Felitti ve Fiore, 2012; QuadriFelitti ve Fiore, 2013) ve tüketicilerin hâlâ hizmet ekonomisini, deneyim ekonomisinden daha önemli olarak algılamaları (Chang, 2018a; Chang, 2018b) ile ilgili eleştirilere maruz kalmaktadır.

\section{KAYNAKÇA}

ALEXIOU, M. V. (2020). "Experience Economy and Co-Creation in A Cultural Heritage Festival: Consumers' Views". Journal of Heritage Tourism, 15(2): 200-216.

ALİ, F., HUSSAIN, K. \& RAGAVAN, N. A. (2014). "Memorable Customer Experience: Examining the Effects of Customers Experience on Memories and Loyalty in Malaysian Resort Hotels". Procedia-Social and Behavioral Sciences, 144(1): 273-279.

ANIL, N. K. (2012). "Festival Visitors' Satisfaction and Loyalty: An Example of Small, Local, and Municipality Organized Festival". Turizam: Međunarodni ZnanstvenoStručni Časopis, 60(3): 255-271.

ANLI, C. K. \& YAVAN, N. (2019). “Deneyim Yaratmada Mekânın Rolü: Starbucks ve Kahve Dünyası'nın Deneyim Ekonomisi ve Üçüncü Yer Bakımından Analizi”. Gaziantep University Journal of Social Sciences, 18(1): 100-132. 
AYOB, N., WAHID, N. A. \& OMAR, A. (2013). "Mediating Effect of Visitors' Event Experiences in Relation to Event Features and Post-Consumption Behaviors". Journal of Convention \& Event Tourism, 14(3), 177-192.

BITNER, M. J. (1992). "Servicescapes: The Impact of Physical Surroundings on Customers and Employees". Journal of Marketing, 56(2): 57-71.

BRUWER, J. (2014). "Service Quality Perception and Satisfaction: Buying Behaviour Prediction in an Australian Festivalscape". International Journal of Tourism Research, 16(1): 76-86.

BRUWER, J. \& KELLEY, K. (2015). "Service Performance Quality Evaluation and Satisfaction in a USA Wine Festivalscape". International Journal of Event and Festival Management, 6(1): 18-38.

CHANG, L. L., BACKMAN, K. F. \& HUANG, Y. C. (2014). "Creative Tourism: A Preliminary Examination of Creative Tourists' Motivation, Experience, Perceived Value and Revisit Intention". International Journal of Culture, Tourism and Hospitality Research, 8(4): 401-419.

CHANG, S. (2018a). "Experience Economy In Hospitality and Tourism: Gain and Loss Values for Service and Experience”. Tourism Management, 64: 55-63.

CHANG, S. (2018b). "Experience Economy in the Hospitality Aad Tourism Context". Tourism Management Perspectives, 27: 83-90.

CHANG, S. H. \& LIN, R. (2015). "Building a Total Customer Experience Model: Applications for the Travel Experiences in Taiwan's Creative Life Industry”. Journal of Travel \& Tourism Marketing, 32(4): 438-453.

ÇULHA, O. \& NEBİOĞLU, O. (2019). "Restoran Deneyiminin Unutulan Yüzü: Deneyim Ekonomisi”. 3. Uluslararası Turizmin Geleceği Kongresi: İnovasyon, Girişimcilik ve Sürdürülebilirlik, ss. 685-693, Mersin, 26-28 Eylül.

DEMİR, A. K. \& YALÇIN, B. (2016). "Genç Tüketicilerin İçecek Tercihlerinin Basamaklama Yöntemi ile Belirlenmesi”. Business \& Economics Research Journal, 7(1): 139-160.

DUAN, B., ARCODIA, C., MA, E. \& HSIAO, A. (2018). “Understanding Wine Tourism in China Using an Integrated Product-Level and Experience Economy Framework". Asia Pacific Journal of Tourism Research, 23(10): 949-960.

HAYES, D. \& MACLEOD, N. (2007). "Packaging Places: Designing Heritage Trails Using an Experience Economy Perspective to Maximize Visitor Engagement". Journal of Vacation Marketing, 13(1): 45-58.

HOSANY, S. \& WITHAM, M. (2010). “Dimensions of Cruisers' Experiences, Satisfaction, and Intention to Recommend”. Journal of Travel Research, 49(3): 351-364.

HWANG, J. \& HAN, H. (2018). “A Study on The Application of The Experience Economy to Luxury Cruise Passengers". Tourism and Hospitality Research, 18(4): 478-491. 
HWANG, J. \& LEE, J. (2019). “A Strategy for Enhancing Senior Tourists' Well-Being Perception: Focusing on the Experience Economy. Journal of Travel \& Tourism Marketing, 36(3): 314-329.

HWANG, J. \& LYU, S. O. (2015). "The Antecedents and Consequences of Well-Being Perception: An Application of the Experience Economy to Golf Tournament Tourists". Journal of Destination Marketing \& Management, 4(4): 248-257.

JUROWSKI, C. (2009, August). "An examination of the Four Realms of Tourism Experience Theory". İçinde International CHRIE Conference-Refereed Track (s. 23).

KANGAL, A. (2013). "Neden-Sonuç Zinciri Teorisi ve Basamaklama Yöntemi: Tüketici Davranışı Araştırmalarında Kullanımı". Business \& Economics Research Journal, 4(2): 55-78.

KARPOV, A. \& MERZLOV, A. (2016). "The Experience Economy Approach to Marketing Les Plus Beaux Villages Brand in Russia". Worldwide Hospitality and Tourism Themes, 8(3): 373-379.

KETTER, E. (2018). "It's All About You: Destination Marketing Campaigns in The Experience Economy Era". Tourism Review, 73(3): 331-343.

KIM, J. H. (2010). "Determining the Factors Affecting The Memorable Nature of Travel Experiences". Journal of Travel \& Tourism Marketing, 27(8): 780-796.

KLENOSKY, D. B., GENGLER, C. E. \& MULVEY, M. S. (1993). "Understanding the Factors Influencing Ski Destination Choice: A Means-End Analytic Approach". Journal of Leisure Research, 25(4): 362-379.

LAI, I. K., LU, D. \& LIU, Y. (2019). "Experience Economy in Ethnic Cuisine: A Case of Chengdu Cuisine". British Food Journal. Makele Yayım Aşamasında. https://doi.org/10.1108/BFJ-08-2018-0517

LEE, S., JEONG, E. \& QU, K. (2019). "Exploring Theme Park Visitors' Experience on Satisfaction and Revisit Intention: A Utilization of Experience Economy Model". Journal of Quality Assurance in Hospitality \& Tourism, 1-24. Makale Yayım Aşamasında.

LO, A., QU, H. \& WETPRASIT, P. (2013). "Realms of Tourism Spa Experience: The Case of Mainland Chinese Tourists". Journal of China Tourism Research, 9(4): 429-451.

LONG, B. \& GOLDENBERG, M. (2010). "A Means-End Analysis of Special Olympics Volunteers". Leisure/Loisir, 34(2): 145-167.

LOUREIRO, S. M. C. (2014). "The Role of the Rural Tourism Experience Economy in Place Attachment and Behavioral Intentions". International Journal of Hospitality Management, 40: 1-9.

MAHDZAR, M., IZHAR, F. S., WEE, H., GHANI, A. A., HAMID, Z. A. \& ANUAR, N. A. M. (2017). "Measuring Experience Economy and Satisfaction: An Examination of Visitors in Agricultural Park". Advanced Science Letters, 23(8): 7574-7577. 
MANHAS, P. S. \& RAMJT (2013). "Customer Experience and its Relative Influence on Satisfaction and Behavioural Intention in Hospitality and Tourism Industry". South Asian Journal of Tourism and Heritage, 6(1): 53-68.

MANTHIOU, A., LEE, S. A., TANG, L. R. \& CHIANG, L. (2014). The Experience Economy Approach to Festival Marketing: Vivid Memory and Attendee Loyalty”. Journal of Services Marketing, 28(1): 22-35.

MASON, M. C. \& PAGGIARO, A. (2009). "Celebrating Local Products: The Role of Food Events". Journal of Foodservice Business Research, 12(4): 364-383.

MEHMETOGLU, M. \& ENGEN, M. (2011). "Pine and Gilmore's Concept Of Experience Economy and Its Dimensions: An Empirical Examination in Tourism”. Journal of Quality Assurance in Hospitality \& Tourism, 12(4): 237-255.

MORGAN, M., ELBE, J. \& DE ESTEBAN CURIEL, J. (2009). "Has the Experience Economy Arrived? The Views of Destination Managers in Three Visitor-Dependent Areas". International Journal of Tourism Research, 11(2): 201-216.

OH, H., FIORE, A. M. \& JEOUNG, M. (2007). "Measuring Experience Economy Concepts: Tourism Applications". Journal of Travel Research, 46(2): 119-132.

OSMOND, A. M., CHEN, T. \& PEARCE, P. L. (2015). "Examining Experience Economy Approaches to Tourists' Anticipated Experiences: Mainland Chinese Travellers Consider Australia". European Journal of Tourism Research, 10: 95-108.

PARK, M., OH, H. \& PARK, J. (2010). "Measuring the Experience Economy of Film Festival Participants". International Journal of Tourism Sciences, 10(2): 35-54.

PIKKEMAAT, B., PETERS, M., BOKSBERGER, P. \& SECCO, M. (2009). "The Staging of Experiences in Wine Tourism". Journal of Hospitality Marketing \& Management, 18(2-3): 237-253.

PINE, B. J. \& GILMORE, J. H. (1998). "Welcome to the Experience Economy". Harvard Business Review, 76: 97-105.

PINE, B. J. \& GILMORE, J. H. (2011). The Experience Economy, Harvard Business Press, Boston.

PINE, B. J. \& GILMORE, J. H. (1999). The Experience Economy: Work is Theatre \& Every Business a Stage, Harvard Business Press, Boston, MA.

QUADRI-FELITTI, D. L. \& FIORE, A. M. (2013). "Destination Loyalty: Effects of Wine Tourists' Experiences, Memories, and Satisfaction On Intentions". Tourism and Hospitality Research, 13(1): 47-62.

QUADRI-FELITTI, D. \& FIORE, A. M. (2012). "Experience Economy Constructs as a Framework for Understanding Wine Tourism”. Journal of Vacation Marketing, 18(1): $3-15$.

RADDER, L. \& HAN, X. (2015). “An Examination of The Museum Experience Based on Pine and Gilmore's Experience Economy Realms". Journal of Applied Business Research (JABR), 31(2): 455-470. 
RIJAL, C. P. \& GHIMIRE, S. (2016). "Prospects of Creating Memorable Experience in Nepalese Tourism and Hospitality Industry". Journal of Tourism and Hospitality Education, 6: 40-66.

RIVERA, M. SEMRAD, K., \& CROES, R. (2015). "The five E's in Festival Experience in the Context of Gen Y: Evidence from a Small Island Destination". Revista Española de Investigación de Marketing ESIC, 19(2): 95-106.

SEMRAD, K. J. \& RIVERA, M. (2018). "Advancing the 5E's in Festival Experience for the Gen Y Framework in the Context of eWOM". Journal of Destination Marketing \& Management, 7: 58-67.

SHIM, C., OH, E. J. \& JEONG, C. (2017). "A Qualitative Analysis of South Korean Casino Experiences: A Perspective on the Experience Economy". Tourism and Hospitality Research, 17(4): 358-371.

SHUYUN, J. \& CHOONG-KI, L. (2017). "Examining Camping Tourists' Experience Using the Experience Economy Theory”. 호텔경영학연구, 26(7): 21-37.

SONG, H. J., LEE, C. K., PARK, J. A., HWANG, Y. H. \& REISINGER, Y. (2015). “The Influence of Tourist Experience on Perceived Value and Satisfaction with Temple Stays: The Experience Economy Theory. Journal of Travel \& Tourism Marketing, 32(4): 401-415.

STASIAK, A. (2013). "Tourist Product in Experience Economy. Turyzm, 23(1): 27-35.

SUNTIKUL, W. \& JACHNA, T. (2016). "Profiling the Heritage Experience in Macao's Historic Center". International Journal of Tourism Research, 18(4): 308-318.

THANH, T. V. \& KIROVA, V. (2018). "Wine Tourism Experience: A Netnography Study." Journal of Business Research, 83: 30-37.

tom DIECK, M. C., JUNG, T. H. \& RAUSCHNABEL, P. A. (2018). "Determining Visitor Engagement through Augmented Reality at Science Festivals: An Experience Economy Perspective". Computers in Human Behavior, 82: 44-53.

WORDART, https://wordart.com/ (Erișim tarihi: 07.12.2019) 